\title{
Review
}

\section{STING Agonists as Cancer Therapeutics}

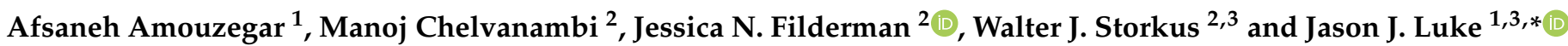 \\ 1 Department of Medicine, University of Pittsburgh, Pittsburgh, PA 15213, USA; amouzegara@upmc.edu \\ 2 Department of Immunology, University of Pittsburgh, Pittsburgh, PA 15213, USA; mac392@pitt.edu (M.C.); \\ JEF116@pitt.edu (J.N.F.); storkuswj@upmc.edu (W.J.S.) \\ 3 UPMC Hillman Cancer Center, Pittsburgh, PA 15232, USA \\ * Correspondence: lukejj@upmc.edu; Tel.: + 412-647-2811; Fax: + 412-623-7948
}

Citation: Amouzegar, A.; Chelvanambi, M.; Filderman, J.N.; Storkus, W.J.; Luke, J.J. STING Agonists as Cancer Therapeutics. Cancers 2021, 13, 2695. https:/ / doi.org/10.3390/cancers13112695

Academic Editor: David J. Waxman

Received: 7 April 2021

Accepted: 24 May 2021

Published: 30 May 2021

Publisher's Note: MDPI stays neutral with regard to jurisdictional claims in published maps and institutional affiliations.

Copyright: (c) 2021 by the authors. Licensee MDPI, Basel, Switzerland. This article is an open access article distributed under the terms and conditions of the Creative Commons Attribution (CC BY) license (https:// creativecommons.org/licenses/by/ $4.0 /)$.
Simple Summary: Immunotherapies have revolutionized the field of cancer therapeutics, yet a substantial subset of patients fail to respond. Recent efforts have focused on identifying targets that could elicit or augment anti-tumor immune responses. One such novel target is STING or stimulator of interferon (IFN) genes, an endoplasmic protein that induces the production of pro-inflammatory cytokines such as type I IFNs. Since the discovery of STING, numerous natural and synthetic STING agonists have been tested in both pre-clinical and clinical settings in different tumors. However, the structural instability of first-generation agonists prompted the development of more stable and potent compounds. This review will highlight the latest pharmacologic classes of STING agonists, novel approaches for tumor-targeted drug delivery, and challenges in the clinical targeting of the STING pathway.

Abstract: The interrogation of intrinsic and adaptive resistance to cancer immunotherapy has identified lack of antigen presentation and type I interferon signaling as biomarkers of non-Tcell-inflamed tumors and clinical progression. A myriad of pre-clinical studies have implicated the cGAS/stimulator of interferon genes (STING) pathway, a cytosolic DNA-sensing pathway that drives activation of type I interferons and other inflammatory cytokines, in the host immune response against tumors. The STING pathway is also increasingly understood to have other anti-tumor functions such as modulation of the vasculature and augmentation of adaptive immunity via the support of tertiary lymphoid structure development. Many natural and synthetic STING agonists have entered clinical development with the first generation of intra-tumor delivered cyclic dinucleotides demonstrating safety but only modest systemic activity. The development of more potent and selective STING agonists as well as novel delivery systems that would allow for sustained inflammation in the tumor microenvironment could potentially augment response rates to current immunotherapy approaches and overcome acquired resistance. In this review, we will focus on the latest developments in STING-targeted therapies and provide an update on the clinical development and application of STING agonists administered alone, or in combination with immune checkpoint blockade or other approaches.

Keywords: stimulator of interferon genes; cGAS; STING agonist; type I interferon; tumor vasculature; anti-tumor immunity; drug delivery

\section{Introduction}

Cancer immunotherapy based on immune-checkpoint blockade has modified cancer treatment paradigms across many tumor types. A major limitation on treatment response to immunotherapy is the inadequate pre-existence of anti-tumor immunity. A number of approaches to initiate de novo immune response have been proposed, with a majority centered on the generation of type I interferons. Of these, agonism of the cGAS/STING pathway is a high priority being pursued for drug development. Here, we discuss the 
rationale for targeting the STING pathway and comprehensively review the field of STING therapeutics from pre-clinical development through completed clinical trials.

\subsection{STING and Type I Interferons in Anti-Tumor Immunity Pattern Recognition Receptors}

Pattern recognition receptors (PRRs) are germline-encoded proteins that play a central role in immune responses against pathogens as well as recognizing danger molecules associated with endogenous injury [1]. PRRs are activated in response to non-self DNA derived from bacteria or viruses or endogenous self-DNA such as cytosolic DNA derived from tumor cells [2]. There are several families of PRRs, including Toll-like receptors (TLRs), RIG-1 like receptors (RLRs), Nod-like receptors (NLRs), C-type lectin receptors (CLRs), and cytosolic DNA sensors such as the Stimulator of Interferon Genes (STING). The STING protein is a PRR which senses cyclic dinucleotides and induces the expression of type I IFN canonically via dendritic cells [3]. Increasing data suggest that the therapeutic effects of many anticancer modalities, including immunotherapies, depend to a large degree on type I IFN signaling [4,5]. The downstream effects of type I IFNs are mediated through the heterodimeric interferon alpha receptor (IFN $\alpha \mathrm{R}$ ), which triggers downstream signaling cascades such as JAK-STAT and induces the transcription of IFN-stimulated genes [6]. Type I IFNs exert a variety of effects on different immune cells, including enhancing the cytotoxic ability of natural killer cells and their potential to secrete IFN- $\gamma[7,8]$, and promoting the differentiation, maturation and migration of antigen-presenting cells [9]. Type I IFN signaling plays a crucial role in innate immune responses, as evidenced by deficient antigen presentation and reduced T cell priming in IFN $\alpha \mathrm{R}$ knockout $\mathrm{CD} 8 \alpha^{+}$dendritic cells [10], and the accelerated metastatic spread of tumor cells in IFN $\alpha$ R knock-out mice [11]. Type I IFNs exert their anti-tumor effects by inhibiting tumor proliferation, and enhancing the expression of MHC class I required for recognition by $\mathrm{CD}^{+} \mathrm{T}$ cells. Increasing numbers of publications are suggesting that type I IFNs also inhibit the expression of vascular endothelial growth factor (VEGF) and therefore exert an inhibitory effect on tumor angiogenesis $[12,13]$.

\subsection{Role of STING in Driving Immune Responses}

STING is a transmembrane protein localized to the endoplasmic reticulum which functions as an adaptor protein in the cGAS (cyclic GMP-AMP synthase)-STING pathway [14]. cGAS-STING is a cytosolic DNA-sensing pathway that drives activation of type I IFN and other inflammatory cytokines in the host immune response against tumors [15]. Recognition of cytoplasmic tumor-derived DNA by c-GAS generates cGAMPs which are natural ligands of STING protein. The binding of cGAMP to STING induces transformational changes in STING protein, activating a downstream signaling cascade involving TBK1 and IRF-3, which results in the production of type I IFNs [16].

Early evidence on the role of the STING pathway in immune homeostasis was derived from associations between constitutive STING activation and DNA-mediated inflammatory disorders. Gain-of-function mutations in TMEM173, the gene encoding STING protein, result in constitutive activation of the STING-IFN- $\beta$ pathway, which is associated with the induction of IFN-response genes such as IP-10. Clinically, the chronic activation of the STING pathway has been linked with an autoinflammatory condition named STINGassociated vasculopathy with onset in infancy (SAVI) $[17,18]$. Symptoms of SAVI usually manifest within the first 8 weeks of life with cutaneous vasculitis, interstitial lung disease and systemic inflammation. Other constitutively active gain-of-function STING mutants have been described as well. A germ-line missense mutation in STING (R284S) was recently described to result in spontaneous STING protein trafficking and downstream signaling in the absence of cGAMP ligand [19]. Another reported mutant STING (G166E) has been associated with the monogenic form of cutaneous lupus. This variant which results from heterozygous mutation in the dimerization domain of the STING causes constitutive type I IFN activation [20]. 
The type I IFN profile and presence of activated $\mathrm{CD} 8^{+} \mathrm{T}$ cells in the tumor microenvironment have been correlated with favorable outcomes in different solid tumors. Studies using mixed bone marrow chimeras with selective IFN $-\alpha / \beta$ sensitivity in either innate or adaptive immune compartments have demonstrated that the effect of type I IFNs is most selectively targeted towards innate immune cells, particularly CD8 $\alpha^{+}$dendritic cells [10]. Further experiments in mice deficient in IFN $\alpha / \beta$ receptor show that these mice are incapable of rejecting tumors, and that DCs derived from these mice are defective in antigen cross-presentation. These observations provided clues to the involvement of an innate immune pathway in driving T-cell-mediated responses to tumors in vivo. Further mechanistic studies showed that mice deficient in STING protein have defects in $\mathrm{CD} 8^{+} \mathrm{T}$ cell priming and fail to reject immunogenic tumors [16], contrary to mice deficient in other immune adaptors such as TLR4, TLR9 or MyD88 that have a normal CD8 ${ }^{+} \mathrm{T}$ cell response.

\subsection{Impact of STING on Tumor Vasculature and Tertiary Lymphoid Structures}

Tumors exhibit genetic instability owing to defects in the expression/functionality of DNA repair proteins [21,22], leading to high intrinsic levels of cytoplasmic DNA and constitutive cGAS/STING activation during tumorigenesis [23-25]. To evade immune surveillance mechanisms instigated by the intrinsic activation of STING in tumor cells, many cancers have evolved defects in the STING signaling pathway [25-27]. Despite such immune evasion mechanisms (including the genomic or epigenetic silencing of STING expression in tumor cells), genetically unstable cancer cells still enrich the TME with high local concentrations of interstitial dsDNA and/or its cGAS catalyzed product $2^{\prime} 3^{\prime}$ cGAMP capable of activating STING ${ }^{+}$stromal cells, including dendritic cells and vascular endothelial cells [28-30]. STING activation within host stromal cells, particularly endothelial cells, leads to increased vascular perfusion and expression of E-selectin, VCAM1 and ICAM-1, in association with improved $\mathrm{T}$ cell adhesion to the endothelium and the facilitated recruitment of tumor-infiltrating lymphocytes [28,31,32]. Indeed, tumor endothelial STING expression has been tightly correlated with enhanced T cell infiltration and prolonged survival in patients with colon and breast cancer [31]. This paradigm may at least partially explain why cancers with reduced DNA repair proficiency and high comparative mutational burden commonly present as immunologically "hot" tumors that have been reported to be more responsive to interventional immunotherapy $[33,34]$.

However, local stimulation of vascular endothelial cells with prohibitively high concentrations of STING agonists results in cellular apoptosis and vascular necrosis/collapse [35-37]. In this light, it is noteworthy that the first-generation STING agonist DMXAA (also known as ASA404 or Vadimezan) was originally developed as a vascular disrupting agent in mice [35]. In early murine tumor models, high-dose (near-MTD) DMXAA-based therapies slowed tumor growth or promoted regression based on vascular necrosis and tumor starvation/hemorrhagic necrosis [36]. However, the tumor microenvironment (TME) remained immunologically sterile/suppressive and treated hosts eventually progressed given a failure to develop durable protective immunity $[38,39]$. Indeed, high local concentrations of STING agonists have been reported to promote rapid T cell apoptosis [40]. Even when combined with alternate immunotherapies, including tumor antigen-specific $\mathrm{CD} 8^{+} \mathrm{T}$ cell transfer, high-dose DMXAA regimens failed to confer superior therapeutic benefits, owing to contraindicated impact on the recruitment and function of immune cells within the TME [38].

Pioneering work has since led to an appreciation that anti-angiogenic/anti-vascular agents may sponsor tumor vascular normalization when applied using low-dose regimens [41,42]. In contrast to high-dose vascular necrosis-inducing effects, low-dose administration of these drugs promotes the selective pruning away of tumor-associated, immature, dysfunctional vessels and the active fortification of mature, functional blood vessels [41]. Therapeutic vascular normalization therefore results in reduced vascular permeability, interstitial fluid pressure and hypoxia within the TME, in concert with improved tumor blood perfusion and the delivery of systemic treatment agents and im- 
mune cells into the TME [31,32,41-43]. Remarkably, tumor vascular normalization also results in "immunologic normalization" in the TME, with suppressor/regulatory or proangiogenic immune cell subsets (regulatory $\mathrm{T}$ cells, myeloid-derived suppressor cells, M2 macrophages) being replaced by pro-inflammatory T cells, M1-macrophages and immunostimulatory antigen-presenting cells [32,41,44]. Recent studies support the ability of low doses of STING agonists cGAMP and ADU-S100 (also known as ML-RR-S2-CDA, MIW815) to promote the local production of anti-angiogenic factors that facilitate vascular normalization when injected intratumorally in mice bearing established breast carcinoma, lung carcinoma or melanoma [31,32]. In keeping with previous reports, the therapeutic efficacy of such intervention was dependent on robust $\mathrm{CD}^{+} \mathrm{T}$ cell infiltration of tumors driven primarily by STING activation in, and type I IFN produced by, tumor vascular endothelial cells $[31,32,45]$.

As suggested by recent studies [32], the ability of STING agonist ADU-S100 to promote a state of sustained inflammation within the TME based on conditional changes in vascular activation and the local production of immune recruiting pro-inflammatory cytokines/chemokines also provides fertile soil for the development of tertiary lymphoid structures (TLS). TLS have been classically associated with tissue sites impacted by autoimmune disease or chronic unresolved pathogenic infections [46-48]. TLS represent lymph-node-like organizations of immune cells that nucleate around specialized highendothelial venules (HEV) that conditionally differentiate from $\mathrm{CD} 31^{+}$vascular endothelial cells or their progenitors in peripheral tissues under pro-inflammatory conditions $[49,50]$. Notably, HEV produce a range of type I IFN-inducible chemokines including CCL21 and CXCL13 [51,52], and they express the canonical peripheral node adhesion molecule (PNAd, a ligand for L-selectin/CD62L), facilitating the recruitment of CCR7 ${ }^{+} \mathrm{CD} 62 \mathrm{~L}^{+}$naïve and central memory T cells, CXCR5 ${ }^{+}$B cells and mature CCR7 ${ }^{+}$dendritic cells into TLS [49,50,53]. Within TLS, T cell- and B cell (germinal center)-centric zones develop, within which T cell cross-priming and B cell affinity maturation may occur, resulting in the locoregional differentiation of $\mathrm{T}$ effector cells and antibody-producing plasma cells that directly fuel protective anti-tumor/pathogen or deleterious autoimmune host responses [54,55]. Consistent with this paradigm, TLS developed in murine B16 melanomas effectively treated with STING agonist ADU-S100 developed a unique T cell receptor (TCR) repertoire that was not observed in the peripheral $\mathrm{T}$ cell population, supporting the operational importance of therapeutic TLS in the melanoma TME. Of major significance, in a series of recent landmark publications, TLS formation in human tumors has been strongly associated with superior patient prognosis and responsiveness to interventional immunotherapies [56-61].

Given the reports supporting the ability of low-dose STING agonists to synergize with alternate anti-angiogenic and immune checkpoint strategies in treating established tumors in translational mouse tumor models, it may be anticipated that such combination and/or sustained (low-dose) delivery regimens will optimize tumor-associated vascular normalization, TLS formation within the TME and the evolution of durable protective antitumor immunity most capable of effectively controlling the progression of antigenically heterogeneous cancers $[31,45,53,62,63]$.

\section{STING Agonists in Clinical Development}

The substantial pre-clinical anti-tumor activity of STING agonists has led to the development of multiple pharmacologic classes of agents at various stages of being translated into the clinic (Figure 1). 

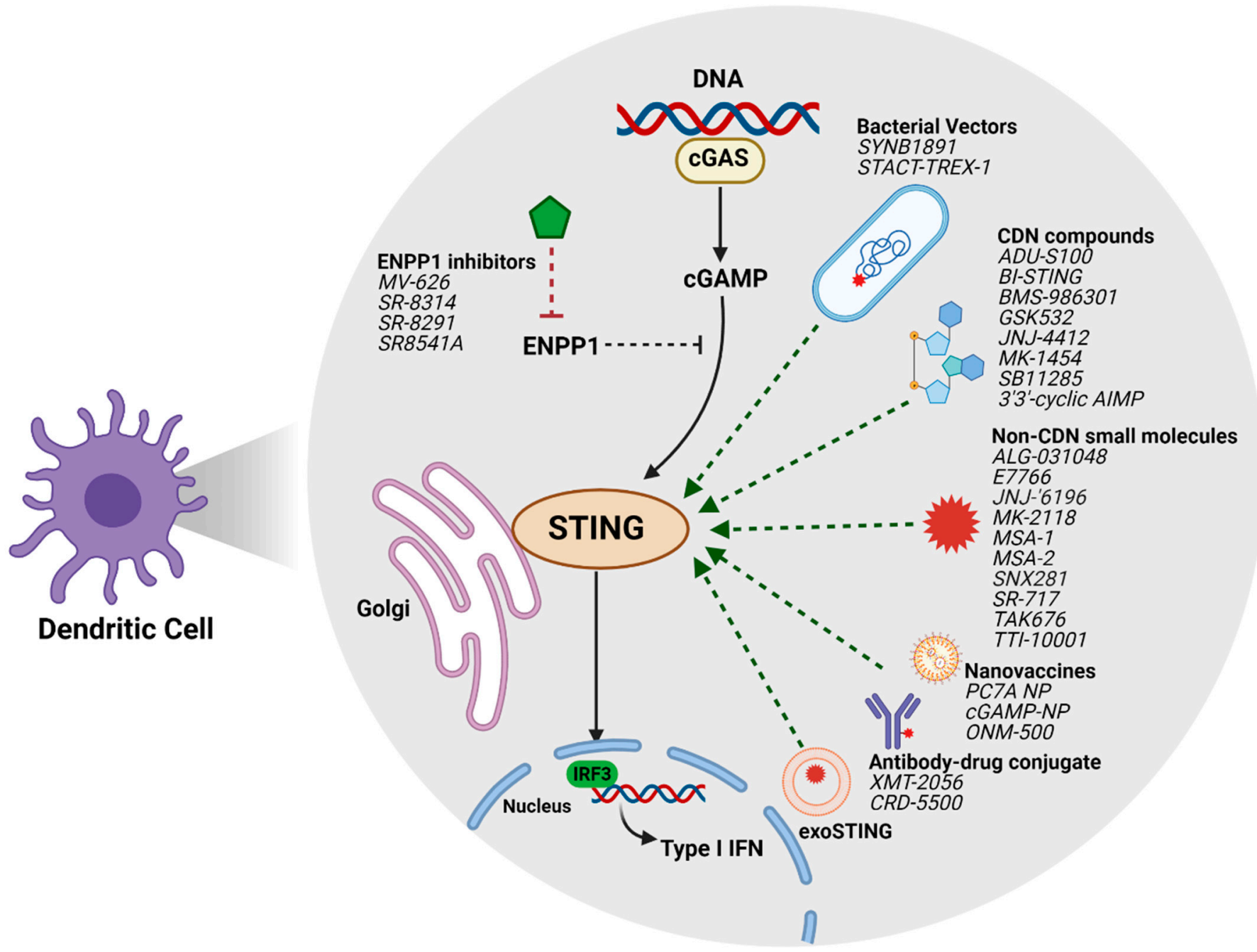

Figure 1. Novel STING agonist strategies and agents in development.

The most prominent tool compound STING agonist broadly used pre-clinically was DMXAA, a vascular disrupting agent known to possess anti-tumor activity. In a randomized phase II clinical trial, feasibility and safety of addition of DMXAA or ASA404 to standard therapy of paclitaxel and carboplatin was assessed in patients with previously untreated advanced non-small cell lung cancer [64]. DMXAA was shown to be welltolerated with limited evidence of adverse events. However, in a subsequent larger phase III randomized trial assessing the efficacy of paclitaxel and carboplatin with or without ASA404 in patients with advanced NSCLC, no difference was observed in overall survival and progression-free survival between the DMXAA-treated vs. placebo groups, resulting in the termination of the trial during interim analysis due to lack of efficacy [65]. This was contrary to pre-clinical studies using murine models, where intratumoral injection of DMXAA was shown to induce a potent anti-tumor immune response $[66,67]$. Detailed studies on the function of DMXAA later showed that while DMXAA is a direct ligand for murine STING, polymorphisms in human STING protein leads to the failed binding of DMXAA, rendering it ineffective in humans [68]. Subsequent efforts were directed towards the development of synthetic agonist compounds with improved stability and lower susceptibility to enzymatic degradation that were capable of binding all known alleles of human STING. 


\subsection{Cyclic Dinucleotides}

Synthetic cyclic dinucleotides (CDNs) were the first class of STING agonists that entered drug development (Table 1).

Table 1. STING agonists in clinical development. HNSCC: head and neck squamous cell carcinoma, IM: intramuscular, IT: intratumoral, IV: intravenous, SQ: subcutaneous.

\begin{tabular}{|c|c|c|c|c|c|}
\hline \multicolumn{2}{|c|}{ Agent } & Route of Delivery & Phase & Type of Cancer & $\begin{array}{c}\text { Clinical Trial NCT } \\
\text { Code }\end{array}$ \\
\hline \multirow{3}{*}{$\begin{array}{c}\text { ADU- } \\
\text { S100/MIW815 }\end{array}$} & $\begin{array}{l}\text { Single agent or }+ \\
\text { Ipilimumab }\end{array}$ & IT & Phase I & $\begin{array}{l}\text { Advanced/Metastatic } \\
\text { Solid Tumors or } \\
\text { Lymphomas }\end{array}$ & NCT02675439 \\
\hline & + Pembrolizumab & IT & Phase II & $\begin{array}{l}\text { PD-L1 positive } \\
\text { recurrent or } \\
\text { metastatic HNSCC }\end{array}$ & NCT03937141 \\
\hline & + PDR001 & IT & Phase Ib & $\begin{array}{l}\text { Advanced/Metastatic } \\
\text { Solid Tumors or } \\
\text { Lymphomas }\end{array}$ & NCT03172936 \\
\hline \multirow{2}{*}{ MK-1454 } & $\begin{array}{l}\text { Single agent or }+ \\
\text { Pembrolizumab }\end{array}$ & IT & Phase I & $\begin{array}{l}\text { Advanced/Metastatic } \\
\text { Solid Tumors or } \\
\text { Lymphomas }\end{array}$ & NCT03010176 \\
\hline & + Pembrolizumab & IT & Phase II & $\begin{array}{c}\text { Metastatic or } \\
\text { Unresectable, } \\
\text { Recurrent HNSCC }\end{array}$ & NCT04220866 \\
\hline MK-2118 & + Pembrolizumab & $\mathrm{IT} / \mathrm{SQ}$ & Phase I & $\begin{array}{l}\text { Advanced/Metastatic } \\
\text { Solid Tumors or } \\
\text { Lymphomas }\end{array}$ & NCT03249792 \\
\hline SB11285 & $\begin{array}{l}\text { Single agent or }+ \\
\text { Atezolizumab }\end{array}$ & IV & Phase Ia / Ib & $\begin{array}{l}\text { Advanced Solid } \\
\text { Tumors }\end{array}$ & NCT04096638 \\
\hline GSK3745417 & $\begin{array}{l}\text { Single agent or }+ \\
\text { Pembrolizumab }\end{array}$ & IV & Phase I & $\begin{array}{l}\text { Advanced Solid } \\
\text { Tumors }\end{array}$ & NCT03843359 \\
\hline BMS-986301 & $\begin{array}{l}\text { Single agent or }+ \\
\text { Nivolumab / } \\
\text { Ipilimumab }\end{array}$ & IT/IM & Phase I & $\begin{array}{c}\text { Advanced Solid } \\
\text { Tumors }\end{array}$ & NCT03956680 \\
\hline $\begin{array}{c}\text { BI-STING (BI } \\
\text { 1387446) }\end{array}$ & $\begin{array}{l}\text { Single agent or }+ \\
\text { BI 754091 } \\
\text { (anti-PD1 } \\
\text { monoclonal } \\
\text { antibody) }\end{array}$ & IT & Phase I & $\begin{array}{l}\text { Advanced Solid } \\
\text { Tumors }\end{array}$ & NCT04147234 \\
\hline E7766 & Single agent & IT & Phase I/Ib & $\begin{array}{l}\text { Advanced Solid } \\
\text { Tumors or } \\
\text { Lymphomas }\end{array}$ & NCT04144140 \\
\hline TAK-676 & $\begin{array}{l}\text { Single agent or }+ \\
\text { Pembrolizumab }\end{array}$ & IV & Phase I & $\begin{array}{l}\text { Advanced Solid } \\
\text { Tumors }\end{array}$ & NCT04420884 \\
\hline SNX281 & $\begin{array}{l}\text { Single agent or }+ \\
\text { Pembrolizumab }\end{array}$ & IV & Phase I & $\begin{array}{l}\text { Advanced Solid } \\
\text { Tumors or } \\
\text { Lymphomas }\end{array}$ & NCT04609579 \\
\hline SYNB1891 & $\begin{array}{l}\text { Single agent or }+ \\
\text { Atezolizumab }\end{array}$ & IT & Phase I & $\begin{array}{l}\text { Advanced Solid } \\
\text { Tumors or } \\
\text { Lymphomas }\end{array}$ & NCT04167137 \\
\hline
\end{tabular}

ADU-S100/MIW815 is a synthetic CDN that mimics natural ligands of STING and can activate all known alleles of human STING. Pre-clinical studies using a range of murine tumor models have shown that intratumoral injection of ADU-S100 leads to induction of 
tumor-specific $\mathrm{CD}^{+} \mathrm{T}$ cells $[69,70]$, and that addition of ADU-S100 to anti-PD1 or antiPD1/anti-CTLA4 antibodies in combination therapies results in enhanced tumor-specific T cell responses and superior anti-tumor efficacy [71,72]. ADU-S100/MIW815 was studied clinically in three clinical trials (NCT03172936, NCT02675439, NCT03937141). In a phase I dose escalation clinical trial, the safety of intratumoral ADU-S100/MIW815 monotherapy (days 1,8 and 15 in a 28-day cycle) was assessed in patients with advanced/metastatic solid tumors or lymphomas (NCT02675439). In this trial involving 40 patients, no dose-limiting toxicities were reported. The most common reported adverse events included pyrexia, pain at the site of injection and headache. Intratumoral injection of ADU-S100/MIW815 was associated with increased levels of inflammatory cytokines such as IL-6, IFN- $\beta 1$ and MCP1/CCL2. Preliminary results showed partial responses in two patients with Merkel cell carcinoma and parotid gland carcinoma, both of whom had previously received anti-PD1 therapy. In addition, 11 out of 40 patients achieved stable disease. The preliminary results of the phase Ib study on ADU-S100/MIW815 in combination with anti-PD1 spartalizumab in patients with advanced/metastatic solid tumors or lymphoma was presented at ASCO 2019 [73]. In this dose escalation study, patients received intratumoral injections of ADUS100 either weekly or every 4 weeks in combination with intravenous spartalizumab. No dose-limiting toxicities were reported, with the most common treatment related adverse events including pain at the site of injection, pyrexia and diarrhea. Increased levels of liver enzymes were reported as grade $3 / 4$ treatment related adverse events (TRAEs) in 3\% of patients. Partial responses were observed in a number of patients with anti-PD1/L1 naïve triple negative breast cancer and anti-PD1 relapsed/refractory melanomas. In the other two ongoing trials, ADU-S100 was clinically tested in combination with pembrolizumab in patients with PD-L1 positive recurrent or metastatic head and neck squamous cell carcinoma (HNSCC) (NCT03937141), and in combination with ipilimumab in patients with advanced/metastatic solid tumors or lymphomas (NCT02675439). Data for these studies has not yet been released, however, these clinical trials have been reported as discontinued.

MK-1454 is synthetic CDN that has advanced into clinical development. The preliminary data of a phase I, open-label, multi-arm first-in-human study on MK-1454 was first publicly released at ESMO 2018 [74]. In this dose escalation study, patients with advanced solid tumors or lymphomas received intratumoral injections of MK-1454 either as monotherapy or in combination with anti-PD1 agent pembrolizumab (NCT03010176). Although no complete or partial responses were observed in the monotherapy arm, 24\% of patients $(6 / 25)$ in the combination therapy arm demonstrated partial responses which were durable for more than 6 months, with $83 \%$ median reduction in size of both injected and non-injected lesions. TRAEs were reported in $83 \%$ of patients in the monotherapy arm and $82 \%$ of patients in the combination therapy arm, of which $9 \%$ and $14 \%$ were grade 3 or higher adverse events respectively, resulting in discontinuation of treatment in $7 \%$ of patients in the combination therapy arm. Reported TRAEs included pain at the injection site, pyrexia, fatigue and pruritus. In patients receiving MK-1454, dose-dependent increases were observed in serum IP-10, STING-induced gene signature, and IL-6 (in smaller subset of patients) in both responder and non-responder groups. Intratumoral MK-1454 is also being tested in patients with metastatic or unresectable recurrent HNSCC as single agent or in combination with pembrolizumab (NCT04220866).

To circumvent the limitations of intratumoral delivery, recent efforts have focused on developing STING agonists with stable physical properties that could be delivered systemically. Although multiple compounds are being developed for systemic delivery in preclinical murine models, only a few have entered clinical testing. SB11285 is a small molecule CDN STING agonist which is being clinically evaluated for intravenous administration in patients with advanced solid tumors. Pre-clinical data using SB11285 in syngeneic mouse models showed significantly higher inhibition of tumor growth in mice injected with intratumoral SB11285 compared to the control group. Additionally, SB11285 in combination with cyclophosphamide resulted in a significant synergistic anti-tumor effect [75]. The ongoing phase 1a/1b non-randomized, dose escalation study on SB11285 aims to 
evaluate the efficacy of intravenous SB11285 either as a single agent or in combination with Atezolizumab in patients with advanced solid tumors (NCT04096638). After determination of dose limiting toxicities and maximum tolerated dose of SB11285, this study aims to assess the anti-tumor activity of IV SB11285 in combination with atezolizumab.

Pre-clinical evaluation of a novel STING agonist BMS-986301 in CT26 and MC38 murine tumor models yielded promising results, with $>90 \%$ complete regression seen in injected and non-injected tumors as opposed to 13\% with ADU-S100. In the CT26 model, a single dose of BMS-986301 combined with anti-PD1 resulted complete regression of $80 \%$ of injected and non-injected tumors when no regressions were seen with anti-PD1 alone [76]. BMS-986301 is currently in clinical testing as intratumoral or intramuscular injection alone or in combination with nivolumab and ipilimumab in patients with advanced solid cancers that have not responded to checkpoint inhibitor therapy (NCT03956680). In subcutaneous syngeneic murine tumor models, a single intratumoral injection of BI-STING, a CDN mimicking natural STING ligand, resulted in dose-dependent anti-tumor activity and inhibition of tumor development upon re-challenge [77]. BI 1387446 is one of the BI-STING compounds that has entered clinical testing. In an ongoing phase I first in human trial, the maximum tolerated dose and tolerability of a single intratumoral injection of BI 1387446 alone or in combination with BI 754091 (an anti-PD1 monoclonal antibody) is being assessed in patients with advanced, unresectable and/or metastatic solid tumors (NCT04147234).

\subsection{Non-Cyclic Dinucleotides}

MK-2118 is a STING agonist of unreported structure which is being tested as an intratumoral or subcutaneous injection alone or in combination with pembrolizumab in patients with advanced solid tumors or lymphomas (NCT03249792). In an early dosing phase 1 clinical trial, GSK3745417, a non-CDN small molecule with dimeric amidobenzimidazole (ABZI) scaffold, is being tested as an intravenous injection either alone or in combination with pembrolizumab in patients with refractory/relapsed solid tumors (NCT03843359). SNX281 is a novel small molecule therapeutic developed as a STING agonist, which is active against all isoforms of human STING and has stable drug properties thus permitting systemic delivery. In pre-clinical models, a single intravenous dose of SNX281 in mice bearing CT26 colorectal tumors resulted in complete regression of tumors. SNX281 also synergized with anti-PD1 agents in inhibiting tumor growth and improving the overall survival of tumor-bearing mice. In an ongoing phase 1 clinical trial, the safety, tolerability and maximum tolerated dose of systemic SNX281 will be assessed in patients with advanced solid tumors and lymphomas. This trial is comprised of two treatment arms, in which intravenous SNX281 is given either as monotherapy or in combination with pembrolizumab, in a dose escalation followed by dose expansion phase to determine the recommended dose for phase 2 studies (NCT04609579). TAK-676 is another small molecule STING agonist with an undisclosed structure that is now under clinical investigation in a phase I dose escalation study. This trial aims to determine the safety and tolerability of intravenous TAK-676 as monotherapy and in combination with pembrolizumab in patients with advanced or metastatic solid tumors (NCT04420884).

E7766 belongs to the novel class of macrocycle-bridged STING agonists (MBSAs). MBSAs show superior in vitro activity against all major human STING genotypes. E7766 binds to both human and mouse STING protein and show activity against a broader range of human STING genotypes compared to reference CDNs. A single intratumoral injection of E7766 was shown to significantly reduce the growth of subcutaneous tumors in mice [78]. In mice bearing CT26 tumors in both subcutaneous tissue and liver, a single intratumoral injection of E776 led to resolution of tumors in $90 \%$ of treated mice with no recurrence over 8 months [79]. Intravesical administration of E7766 in mice with BCG-unresponsive non-muscle invasive bladder cancer was associated with robust IFN- $\beta$ gene induction and a dose-dependent anti-tumor response [80]. The clinical efficacy of intratumoral injection of E7766 is being evaluated in a phase $1 / 1 \mathrm{~b}$ clinical trial as a monotherapy in patients with advanced solid tumors or lymphomas (NCT04144140). 


\subsection{Bacterial Vectors}

Bacterial vectors have been used as a novel approach for delivering STING agonists to intratumoral antigen-presenting cells. One such vector is SYNB1891, a non-pathogenic $E$. Coli Nissle strain engineered to express cyclic di-AMP-producing enzymes in response to the hypoxic environment of tumor, while remaining localized to the tumor microenvironment. Pre-clinical studies show that intratumoral injection of SYNB1891 to B16.F10 melanoma tumor-bearing mice induces production of type I IFNs and leads to significant reduction in tumor growth eight days after treatment [81]. In an ongoing phase I clinical trial, anti-tumor efficacy of intratumoral SYNB1891 as monotherapy or in combination with Atezolizumab is being evaluated in patients with advanced/metastatic solid tumors and lymphoma (NCT04167137). Another novel bacterial-based immunotherapy is STACT, an attenuated Salmonella Typhimurium strain that carries an inhibitory microRNA to TREX-1. TREX-1 exonuclease prevents activation of STING pathway by degrading cytosolic DNA. Preclinical studies show that intravenously delivered STACT-TREX-1 specifically colonizes to the myeloid compartment of the tumor microenvironment [82]. In CT26 and MC38 murine models, intravenous injection of STACT-TREX-1 was associated with very low systemic levels of inflammatory cytokines, demonstrating tumor specific colonization of STACTTREX-1, tumor regression and durable immunity upon re-challenge [83]. STACT-TREX-1 is advantageous over early-generation STING agonists as it can be administrated systemically and thus can target a wider range of tumors. This platform is yet to enter clinical testing.

\section{STING Agonists in Pre-Clinical Evaluations}

The chemical structure and stability of many clinically developed STING agonists have limited their use as systemic immunotherapeutics. In the past few years, novel cyclic CDN and non-CDN STING agonist compounds with improved structural properties, higher potency and affinity towards human STING, and with potential for systemic delivery have been identified and shown promising results in pre-clinical studies (Table 2).

\subsection{Novel Cyclic Dinucleotides}

JNJ-67544412 (JNJ-4412) is a recently developed CDN STING agonist, which is claimed to bind to all major alleles of human STING with a stronger affinity than other known CDNs. In syngeneic mouse tumor models, intratumoral injection of JNJ-4412 was shown to result in increased levels of pro-inflammatory cytokines in tumor and plasma, increased frequencies of $\mathrm{CD}^{+} \mathrm{T}$ cells, loss of vascularization, increased apoptosis and significant regression of both injected and contralateral tumors. Transient body weight loss was reported as an adverse event but was alleviated with less frequent dosing [84]. In a recent study, $3^{\prime} 3^{\prime}$-cyclic AIMP developed as a CDN STING agonist was tested in a murine model of hepatocellular carcinoma (HCC). Intraperitoneal injection of $3^{\prime} 3^{\prime}$-cyclic AIMP to STINGdeficient mice with HCC resulted in a reduced tumor burden exemplified by smaller liver surface nodules, an increased number of $\mathrm{CD} 8^{+} \mathrm{T}$ cells and increased apoptotic cell death within the tumor. When $3^{\prime} 3^{\prime}$-cyclic AIMP was administered at a later stage after HCC development, tumor regression was observed in the majority of tumors; however, new tumors developed that were not responsive to CDN treatment, supporting the efficacy of this agent in reducing tumor burden but its inability to completely resolve all lesions in multi-focal disease models [106]. Another novel CDN, GSK532, has shown improved stability with minimal degradation in human whole blood, and is able to induce cytokine responses in human cells with different STING haplotypes. In addition, intratumoral injection of GSK532 to mice harboring CT26 tumor cells was shown to induce anti-tumor responses in both injected and uninjected tumors [86]. This compound is yet to enter clinical testing. 
Table 2. STING-targeting compounds in pre-clinical stage.

\begin{tabular}{|c|c|c|c|c|c|}
\hline Agent & Structure/Properties & $\begin{array}{l}\text { Route of } \\
\text { Delivery }\end{array}$ & Tumor Model & Findings & References \\
\hline \multicolumn{6}{|c|}{ Cyclic dinucleotide (CDN) } \\
\hline $\begin{array}{c}\text { JNJ-67544412 } \\
\text { (JNJ-4412) }\end{array}$ & $\begin{array}{l}\text { Cyclic } \\
\text { dinucleotide, } \\
\text { Potently binds to } \\
\text { all major human } \\
\text { STING alleles }\end{array}$ & Intratumoral & $\begin{array}{l}\text { Subcutaneous } \\
\text { syngeneic } \\
\text { murine tumor } \\
\text { models }\end{array}$ & 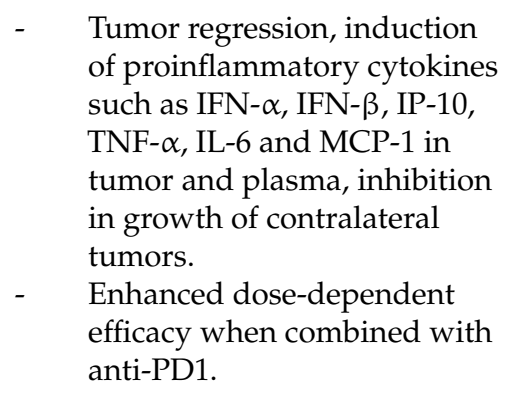 & {$[84]$} \\
\hline BI-STING & $\begin{array}{l}\text { Mimics natural } \\
\text { STING ligand }\end{array}$ & Intratumoral & $\begin{array}{l}\text { Subcutaneous } \\
\text { syngeneic } \\
\text { murine tumor } \\
\text { models }\end{array}$ & $\begin{array}{l}\text { - } \\
\text { Single dose of intratumoral } \\
\text { BI-STING results in transient } \\
\text { increase in cytokine levels, } \\
\text { dose-dependent local tumor } \\
\text { control. No tumor developed } \\
\text { upon re-challenge. } \\
\text { Tumor control improved } \\
\text { when combined with } \\
\text { anti-PD1 } \\
\text { ELISPOT: higher number of } \\
\text { immunospots in splenocytes } \\
\text { from BI-STING-treated } \\
\text { animals showing induction of } \\
\text { tumor specific immune } \\
\text { response. }\end{array}$ & [77] \\
\hline $\begin{array}{c}3^{\prime} 3^{\prime} \text {-cyclic } \\
3^{\prime} 3^{\prime} \text {-cAIMP }\end{array}$ & Cyclic dinucleotide & Not specified & $\begin{array}{l}\text { Mouse model of } \\
\text { mutagen- } \\
\text { induced } \\
\text { hepatocellular } \\
\text { carcinoma }\end{array}$ & $\begin{array}{l}\text { Treatment of mice after HCC } \\
\text { development efficiently } \\
\text { reduced tumor size. } \\
\text { Initiation of treatment at later } \\
\text { stage of disease development } \\
\text { resulted in regression of the } \\
\text { majority of tumors, but new } \\
\text { treatment-unresponsive } \\
\text { tumors were detected. }\end{array}$ & [85] \\
\hline GSK532 & Cyclic dinucleotide & Intratumoral & $\begin{array}{c}\text { CT26 murine } \\
\text { syngeneic model }\end{array}$ & $\begin{array}{l}\text { - } \quad \text { Strong anti-tumor effect in } \\
\text { both the injected and } \\
\text { uninjected tumors. } \\
\text { - Cured mice were resistant to } \\
\text { re-challenge with the same } \\
\text { tumor cell line. }\end{array}$ & [86] \\
\hline \multicolumn{6}{|c|}{ Non-CDN Agonists } \\
\hline $\begin{array}{l}\text { Ryvu's } \\
\text { agonists }\end{array}$ & $\begin{array}{c}\text { Selective } \\
\text { non-nucleotide, } \\
\text { non-macrocyclic, } \\
\text { small molecule } \\
\text { compounds, } \\
\text { potential for } \\
\text { systemic } \\
\text { administration }\end{array}$ & Not specified & $\begin{array}{c}\text { CT26 murine } \\
\text { syngeneic model }\end{array}$ & $\begin{array}{l}\text { Dose-dependent upregulation } \\
\text { of STING-dependent } \\
\text { pro-inflammatory cytokines. } \\
\text { Complete tumor remission } \\
\text { and development of } \\
\text { immunological memory } \\
\text { against cancer cells. }\end{array}$ & [87] \\
\hline
\end{tabular}


Table 2. Cont

\begin{tabular}{|c|c|c|c|c|c|}
\hline Agent & Structure/Properties & $\begin{array}{l}\text { Route of } \\
\text { Delivery }\end{array}$ & Tumor Model & Findings & References \\
\hline GF3-002 & $\begin{array}{l}\text { Novel } \\
\text { low-molecular-weight } \\
\text { organic molecule, not } \\
\text { based on a CDN }\end{array}$ & In vitro & In vitro assays & $\begin{array}{l}\text { - Confirmed binding to WT } \\
\text { STING and production of } \\
\text { IFN- } \beta \text { after treatment of } \\
\text { dendritic cells with GF3-002. }\end{array}$ & [88] \\
\hline $\begin{array}{l}\text { Selvita } \\
\text { agonists }\end{array}$ & $\begin{array}{c}\text { Selective } \\
\text { non-nucleotide, } \\
\text { non-macrocyclic, small } \\
\text { molecule compounds, } \\
\text { structurally unrelated } \\
\text { to known CDNs, } \\
\text { tunable properties } \\
\text { with enhanced plasma } \\
\text { stability and } \\
\text { permeability, potential } \\
\text { for systemic } \\
\text { administration }\end{array}$ & In vitro & In vitro assays & 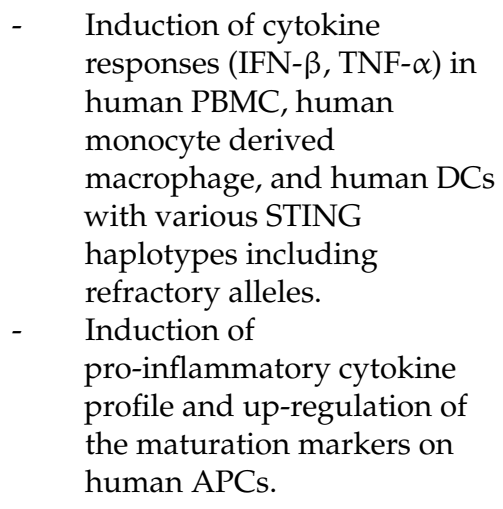 & [89] \\
\hline TTI-10001 & $\begin{array}{l}\text { Non-CDN small } \\
\text { molecule STING } \\
\text { agonist }\end{array}$ & Intratumoral & $\begin{array}{l}\text { Multiple } \\
\text { syngeneic } \\
\text { murine tumor } \\
\text { models }\end{array}$ & $\begin{array}{l}\text { Well-tolerated in vivo; results } \\
\text { in increased expression of } \\
\text { pro-inflammatory cytokines, } \\
\text { and anti-tumor activity. }\end{array}$ & [90] \\
\hline JNJ-'6196 & $\begin{array}{l}\text { Next-generation } \\
\text { STING agonist; binds } \\
\text { to STING with weaker } \\
\text { affinity and a faster off } \\
\text { rate, but more potent } \\
\text { than other CDNs in } \\
\text { activating dendritic } \\
\text { cells }\end{array}$ & Intravenous & $\begin{array}{l}\text { Murine tumor } \\
\text { models (not } \\
\text { specified) }\end{array}$ & $\begin{array}{l}\text { - Eliminates bilateral tumors, } \\
\text { and provides immunity to } \\
\text { further re-challenge. } \\
\text { - Increases the effectiveness of } \\
\text { checkpoint inhibitors, turning } \\
\text { a PD-1 resistant model into a } \\
\text { responsive model. }\end{array}$ & [91] \\
\hline CRD5500 & $\begin{array}{l}\text { Next-generation small } \\
\text { molecule STING } \\
\text { agonist. Activates all } \\
\text { five common human } \\
\text { STING variants. } \\
\text { Delivery via different } \\
\text { routes (IV or SC) or as } \\
\text { an antibody drug } \\
\text { conjugate }\end{array}$ & $\begin{array}{c}\text { Intravenous, } \\
\text { subcutaneous, } \\
\text { Antibody-drug } \\
\text { conjugate (ADC) } \\
\text { with } \\
\text { Trastuzumab }\end{array}$ & $\begin{array}{l}\text { CT26 syngeneic } \\
\text { murine model }\end{array}$ & $\begin{array}{l}\text { - In vitro: causes maturation of } \\
\text { hDCs and the release of } \\
\text { innate and adaptive } \\
\text { inflammatory cytokines such } \\
\text { as IFN- } \beta \text { and TNF- } \alpha \text {. } \\
\text { In vivo administration (IT or } \\
\text { systemically): tumor } \\
\text { regression in CT26 syngeneic } \\
\text { tumors containing human } \\
\text { STING. }\end{array}$ & [92] \\
\hline $\begin{array}{l}\text { CS-1018, } \\
\text { CS-1020 } \\
\text { and } \\
\text { CS-1010 }\end{array}$ & $\begin{array}{l}\text { STING agonists with } \\
\text { higher potency in } \\
\text { activating mouse and } \\
\text { human STING } \\
\text { variants than natural } \\
\text { ligand cGAMP }\end{array}$ & Intratumoral & $\begin{array}{l}\text { B16F10 and } \\
\text { MC } 38 \text { murine } \\
\text { tumor models }\end{array}$ & 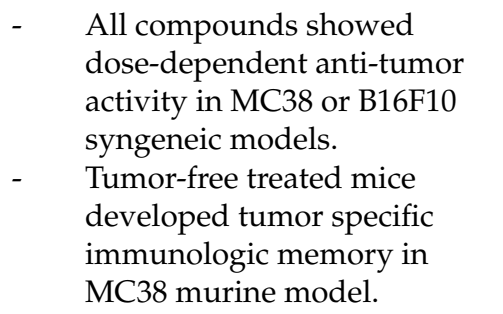 & [93] \\
\hline
\end{tabular}


Table 2. Cont

\begin{tabular}{|c|c|c|c|c|c|}
\hline Agent & Structure/Properties & $\begin{array}{l}\text { Route of } \\
\text { Delivery }\end{array}$ & Tumor Model & Findings & References \\
\hline $\begin{array}{l}{[-2 \mathrm{ex}]} \\
\text { MSA-1 }\end{array}$ & $\begin{array}{l}\text { Novel STING agonist } \\
\text { with higher potency in } \\
\text { activating STING } \\
\text { protein than cGAMP }\end{array}$ & Intratumoral & $\begin{array}{l}\text { MC38 syngeneic } \\
\text { tumors, CT26 } \\
\text { and B16-F10 } \\
\text { tumor models }\end{array}$ & $\begin{array}{l}\text { - } \quad \text { Complete responses observed } \\
\text { in } 100 \% \text { of MC38 tumors. } \\
\text { - Restoration of T cell responses } \\
\text { (in serum and tumors) of mice } \\
\text { with anti-PD1 unresponsive } \\
\text { tumors when combined with } \\
\text { anti-PD1. }\end{array}$ & [94] \\
\hline $\begin{array}{c}\text { ALG- } \\
031048\end{array}$ & $\begin{array}{l}\text { Novel STING agonist } \\
\text { with high potency and } \\
\text { superior stability }\end{array}$ & $\begin{array}{l}\text { Intratumoral, } \\
\text { Subcutaneous }\end{array}$ & $\begin{array}{l}\text { Syngeneic CT26 } \\
\text { colorectal, } \\
\text { B16F10 } \\
\text { melanoma, and } \\
\text { Hepa1-6 HCC } \\
\text { models }\end{array}$ & 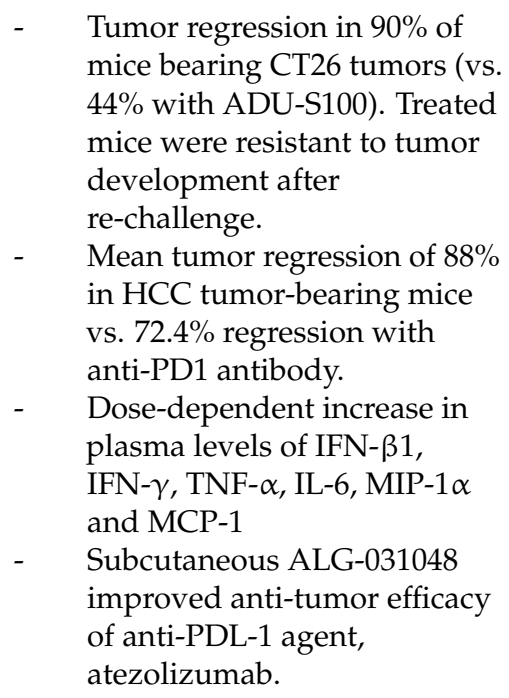 & [95] \\
\hline \multicolumn{6}{|c|}{ Macrocyclic STING Agonist } \\
\hline E7766 & $\begin{array}{l}\text { Macrocyclic STING } \\
\text { agonist with superior } \\
\text { in vitro activity } \\
\text { against all major } \\
\text { human STING } \\
\text { genotypes, chemical } \\
\text { and metabolic stability, } \\
\text { conferred by } \\
\text { conformational } \\
\text { rigidity of the unique } \\
\text { macrocycle bridge }\end{array}$ & $\begin{array}{l}\text { Intravesical, } \\
\text { Intratumoral }\end{array}$ & $\begin{array}{l}\text { Murine anti-PD1 } \\
\text { insensitive } \\
\text { NMIBC tumor } \\
\text { models, } \\
\text { subcutaneous } \\
\text { tumor models }\end{array}$ & $\begin{array}{l}\text { Intravesical: dose-dependent } \\
\text { anti-tumor effect vs. anti-PD1 } \\
\text { which was ineffective. } \\
\text { Tumor-free animals rejected } \\
\text { re-challenge of same tumor } \\
\text { cell line. Activation of IFN } \\
\text { pathway, T cell infiltration, } \\
\text { NK activity, induction of } \\
\text { IFN- } \beta \text { and CXCL10 inside the } \\
\text { bladder cavity and in the } \\
\text { urine. } \\
\text { Intratumoral: single IT } \\
\text { injection led to complete } \\
\text { regression or significant } \\
\text { tumor growth delay. }\end{array}$ & {$[78,80]$} \\
\hline
\end{tabular}

ENPP1 Inhibitor

SR-8541A Small molecule ENPP1 inhibitor
In vitro
In vitro assays
Stimulates the migration and infiltration of immune cells (PBMC) into cancer spheroids, increases expression of IFN- $\beta$, ISG15 and CXCL10. models confirmed that the drug effect is ENPP1-dependent. 
Table 2. Cont

\begin{tabular}{|c|c|c|c|c|c|}
\hline Agent & Structure/Properties & $\begin{array}{l}\text { Route of } \\
\text { Delivery }\end{array}$ & Tumor Model & Findings & References \\
\hline SR-8314 & $\begin{array}{l}\text { Analog of SR-8291 (a } \\
\text { highly selective } \\
\text { ENPP1 inhibitor) }\end{array}$ & Intraperitoneal & $\begin{array}{l}\text { Syngeneic } \\
\text { murine tumor } \\
\text { model }\end{array}$ & $\begin{array}{l}\text { Increase in gene expression of } \\
\text { IFN- } \beta, \text { ISG15 and CXCL10 } \\
\text { and secretion of IFN- } \beta \text { in } \\
\text { SR-8314-treated THP1 cells. } \\
\text { Anti-tumor activity, increase } \\
\text { in CD3 }{ }^{+}, \text {CD } 4^{+} \text {and CD8 }{ }^{+} \mathrm{T} \\
\text { cells in both SR-8314 and } \\
\text { SR-8291-treated tumors, } \\
\text { decrease in tumor-associated } \\
\text { macrophages in } \\
\text { SR-8314-treated tumors. }\end{array}$ & [97] \\
\hline $\begin{array}{l}\text { Orally } \\
\text { available } \\
\text { ENPP1 } \\
\text { inhibitors }\end{array}$ & $\begin{array}{l}\text { Small molecule } \\
\text { compounds with } \\
\text { strong binding affinity } \\
\text { towards ENPP1 }\end{array}$ & In vitro & In vitro assays & $\begin{array}{l}\text { - Specific and high binding } \\
\text { affinity to ENPP1 with no } \\
\text { effect on other members of the } \\
\text { ENPP family, activation of } \\
\text { STING pathway. } \\
\text { One of lead compounds is } \\
\text { currently under investigation } \\
\text { for ADME-Tox, PK and } \\
\text { efficacy. }\end{array}$ & [98] \\
\hline MV-626 & $\begin{array}{c}\text { Selective ENPP1 } \\
\text { inhibitor with 100\% } \\
\text { oral bioavailability }\end{array}$ & Intraperitoneal & $\begin{array}{l}\text { Panc02-SIY and } \\
\text { MC38 murine } \\
\text { tumor models }\end{array}$ & $\begin{array}{l}\text { Therapeutic doses were well } \\
\text { tolerated in mice, without } \\
\text { toxicity or clinically } \\
\text { significant increases in } \\
\text { systemic cytokine levels. } \\
\text { Systemic MV- } 626 \\
\text { monotherapy caused tumor } \\
\text { growth delay. MV-626 plus } \\
\text { radiation therapy significantly } \\
\text { increased overall survival. }\end{array}$ & [99] \\
\hline \multicolumn{6}{|c|}{ Novel Delivery Systems } \\
\hline $\begin{array}{l}\text { Antibody } \\
\text { drug } \\
\text { conjugates } \\
\text { (ADC) }\end{array}$ & STING agonist ADCs & Intravenous & $\begin{array}{c}\text { Multiple } \\
\text { xenograft and } \\
\text { syngeneic } \\
\text { murine models }\end{array}$ & $\begin{array}{l}\text { 100-fold more potency in } \\
\text { inducing inflammatory } \\
\text { cytokine expression compared } \\
\text { to free agonist. } \\
\text { - } \quad \text { Inflammatory cytokines were } \\
\text { tumor localized while } \\
\text { systemic levels remained low. } \\
\text { Single IV injection of targeted } \\
\text { STING ADC in tumor-bearing } \\
\text { mice significantly inhibited } \\
\text { tumor growth compared to } \\
\text { systemically injected diABZI. }\end{array}$ & [100] \\
\hline
\end{tabular}


Table 2. Cont

\begin{tabular}{|c|c|c|c|c|c|}
\hline Agent & Structure/Properties & $\begin{array}{l}\text { Route of } \\
\text { Delivery }\end{array}$ & Tumor Model & Findings & References \\
\hline $\begin{array}{l}\text { ONM-500 } \\
\text { nanovac- } \\
\text { cine }\end{array}$ & $\begin{array}{l}\text { Novel } \mathrm{pH} \text {-sensitive } \\
\text { polymer that forms an } \\
\text { antigen-encapsulating } \\
\text { nanoparticle and } \\
\text { functions both as a } \\
\text { carrier for antigen } \\
\text { delivery to DCs and as } \\
\text { an adjuvant, activating } \\
\text { the STING pathway }\end{array}$ & Subcutaneous & $\begin{array}{l}\text { TC-1 cervical } \\
\text { cancer murine } \\
\text { model }\end{array}$ & $\begin{array}{l}\text { - } \quad \text { Effective binding to human } \\
\text { STING protein. } \\
\text { - } \quad \text { Effective delivery of antigens } \\
\text { in vivo to LNs to elicit an } \\
\text { antigen-specific CTL } \\
\text { response. } \\
\text { ONM-500 nanovaccine } \\
\text { containing full-length E6/E7 } \\
\text { protein resulted in 100\% } \\
\text { overall survival of TC-1 } \\
\text { bearing mice at } 55 \text { days. } \\
\text { Long-term antigen-specific } \\
\text { anti-tumor memory response } \\
\text { in re-challenge study. }\end{array}$ & [101] \\
\hline $\begin{array}{l}\text { Neoantigen } \\
\text { nanovac- } \\
\text { cine }\end{array}$ & $\begin{array}{c}\text { Redox-responsive } \\
\text { neoantigen-polymer } \\
\text { conjugates and a } \\
\text { STING agonist } \\
\text { DMXAA }\end{array}$ & Subcutaneous & $\begin{array}{c}\text { B16-F10 } \\
\text { melanoma } \\
\text { murine model }\end{array}$ & $\begin{array}{l}\text { Nanovaccine combined with } \\
\text { anti-PD1 treatment led to } 50 \% \\
\text { survival rate on day } 38 \\
\text { compared to } 20 \% \text { in mice } \\
\text { receiving non-formulated } \\
\text { neoantigen peptides. }\end{array}$ & [102] \\
\hline exoSTING & $\begin{array}{l}\text { Engineered exosome } \\
\text { therapeutic that } \\
\text { delivers STING } \\
\text { agonist to tumor } \\
\text { resident APCs }\end{array}$ & Intratumoral & $\begin{array}{l}\text { Checkpoint } \\
\text { refractory } \\
\text { B16-F10 } \\
\text { melanoma } \\
\text { murine model }\end{array}$ & $\begin{array}{l}\text { exoSTING is retained within } \\
\text { the injected tumor, and does } \\
\text { not induce systemic cytokine } \\
\text { production. } \\
\text { exoSTING treatment results in } \\
\text { significant induction of PD-L1 } \\
\text { expression. In combination } \\
\text { with PD1 checkpoint } \\
\text { blockade, exoSTING shows } \\
\text { enhanced anti-tumor efficacy } \\
\text { over high-dose free STING } \\
\text { agonist. }\end{array}$ & {$[103,104]$} \\
\hline $\begin{array}{l}\text { STACT- } \\
\text { TREX1 }\end{array}$ & $\begin{array}{l}\text { Inhibitory microRNA } \\
\text { to TREX1, introduced } \\
\text { into the STACT strain. }\end{array}$ & Intravenous & $\begin{array}{l}\text { CT26 and MC38 } \\
\text { colon carcinoma } \\
\text { models, and } \\
\text { B16-F10 } \\
\text { melanoma model }\end{array}$ & $\begin{array}{l}\text { - } \quad \text { Tumor-specific colonization of } \\
\text { STACT-TREX1, immune } \\
\text { correlates consistent with } \\
\text { STING activation and CD8 }{ }^{+} \\
\text {T-cell-dependent immune } \\
\text { response. } \\
\text { Potent tumor growth } \\
\text { inhibition and complete } \\
\text { tumor regressions with } \\
\text { STACT-TREX1 monotherapy. } \\
\text { Immunity to tumor } \\
\text { re-challenge }\end{array}$ & {$[82,83]$} \\
\hline
\end{tabular}


Table 2. Cont

\begin{tabular}{|c|c|c|c|c|c|}
\hline Agent & Structure/Properties & $\begin{array}{l}\text { Route of } \\
\text { Delivery }\end{array}$ & Tumor Model & Findings & References \\
\hline $\begin{array}{l}\text { STING- } \\
\text { NPs }\end{array}$ & $\begin{array}{c}\text { Liposomal } \\
\text { nanoparticles (NPs) to } \\
\text { deliver the STING } \\
\text { agonist, cGAMP }\end{array}$ & Intravenous & $\begin{array}{c}\text { Basal-like } \\
\text { triple-negative } \\
\text { breast cancer } \\
\text { (TNBC) murine } \\
\text { model }\end{array}$ & $\begin{array}{l}\text { cGAMP-NPs accumulate } \\
\text { within macrophages at the } \\
\text { tumor, induce M2 to M1-like } \\
\text { phenotype, MHC and } \\
\text { co-stimulatory molecule } \\
\text { expression, enhanced CD4 } \\
\text { and CD8 }{ }^{+} \text {T cell infiltration, } \\
\text { and tumor apoptosis. } \\
\text { Effective tumor suppression } \\
\text { achieved in anti-PD-L1 } \\
\text { non-responsive tumors. } \\
\text { Induction of durable } \\
\text { anti-tumor T cell responses } \\
\text { and prevention of secondary } \\
\text { tumor development. }\end{array}$ & [105] \\
\hline
\end{tabular}

\subsection{Next-Generation Non-Cyclic Dinucleotides}

TTI-10001 is a non-CDN small molecule STING agonist which is able to bind to all five human STING alleles as well as to the murine STING protein. Intratumoral administration of TTI-10001 in murine models of syngeneic tumors was found to be safe and associated with increased levels of phospho-IRF3, pro-inflammatory cytokines, and anti-tumor activity [90]. Selvita agonists are a group of recently developed small-molecule, non-nucleotide, non-macrocyclic STING agonists. These agonists selectively bind to both mouse and human STING proteins and have tunable properties with enhanced plasma stability and permeability, making them potential candidates for systemic delivery [89]. In vitro studies on peripheral blood mononuclear cells and the THP1 monocytic cell line show that Selvita agonists induce the expression of inflammatory cytokines and upregulate maturation markers on the surface of APCs. A group of selective non-CDN non-macrocylic small molecule compounds (Ryvu's agonists) have shown promising results in pre-clinical animal models [87]. These agonists bind to STING proteins of different species and are able to induce DC maturation and cytokine expression from human PBMCs irrespective of the STING haplotype. Systemic administration of these compounds (route not specified) in mice bearing CT26 colorectal cancer cells resulted in complete tumor regression and the development of immunological memory [87].

ALG-031048 is a novel STING agonist that has shown higher stability in in vitro studies compared to natural STING ligand and STING agonist ADU-S100. Intratumoral injection of ALG-031048 in mice bearing CT26 tumor cells resulted in tumor regression in $90 \%$ of mice (compared to $44 \%$ with ADU-S100). Treated mice were resistant to tumor development after re-challenge with the same tumor cell line [95]. In another study, intratumoral injection of ALG-031048 to mice bearing Hepa1-6 hepatocellular carcinoma tumor cells resulted in a mean tumor regression of $88 \%$ compared to $72.4 \%$ regression after treatment with anti-PD1 antibody. Treatment with ALG-031048 was associated with a dose-dependent increase in the level of cytokines such as IFN- $\beta 1$, IFN- $\gamma$, TNF- $\alpha$, IL-6, MIP- $1 \alpha$ and MCP-1. The anti-tumor efficacy of ALG-031048 was also shown after subcutaneous injection, and the combination of subcutaneous ALG-031048 with anti-PDL-1 agent, atezolizumab, further enhanced tumor growth inhibition from $60 \%$ with atezolizumab alone to $77 \%$ with combination therapy [107]. MSA-1 STING agonist compound has also shown robust anti-tumor efficacy when injected intratumorally to mice bearing MC38 syngeneic colon carcinomas. Complete responses were observed in 100\% of tumors in mice receiving the highest tolerated dose of intratumoral MSA-1. Combination of MSA-1 with anti-PD1 antibody (mDX400) resulted in 
the restoration of $\mathrm{T}$ cell responses in anti-PD1 unresponsive tumors, further supporting the synergic anti-tumor activity of STING agonists with anti-PD1 therapy [94]. CRD-5500, a next-generation small molecule STING agonist, has shown to be effective via intratumoral and systemic routes and also as an antibody-drug conjugate with Trastuzumab. The fact that CRD-5500 can be dosed via multiple routes makes it a favorable agent for future clinical development. Pre-clinical data show that both intravenous and intratumoral injections of CRD-5500 induce tumor regression in murine CT26 colon carcinoma models engineered to express human STING, and this anti-tumor effect is further amplified when CRD-5500 is combined with check point inhibitor therapy [92].

\subsection{ENPP1 Inhibitors}

ENPP1 is a transmembrane phosphodiesterase known for its central role in purinergic signaling [108]. Recent studies show that ENPP1 can downregulate cGAS-STING signaling by hydrolyzing cGAMP, the natural STING ligand [109]. This finding mainly stems from observations that cGAMP derived from ENPP1 knock-out cells has a higher ability to activate STING, and the in vitro inhibition of ENPP1 amplifies cGAS-STING signaling [110]. Orally available small molecules that inhibit ENPP1 have been developed as novel STING agonists [98]. In one such study, small molecule compounds with strong binding affinity towards ENPP1 were identified using computational methods and direct binding assays. These compounds were shown to bind specifically to ENPP1 vs. other members of the ENPP family and to activate the STING pathway [98]. $M V-626$ is a selective ENPP1 inhibitor with $100 \%$ bioavailability that has been studied in pre-clinical models. Intraperitoneal injection of MV-626 alone or in combination with radiation therapy in mice implanted with Panc02-SIY pancreatic adenocarcinoma tumors resulted in a durable anti-tumor immune response and improved overall survival [99]. $S R-8314$ and $S R-8291$ are both highly selective ENPP1 inhibitors that have shown promising in vivo efficacy in syngeneic murine tumor models. Intraperitoneal injection of SR-8314 and SR-8291 led to increased frequencies of $\mathrm{CD}^{+}$and $\mathrm{CD} 8^{+} \mathrm{T}$ cells and a decrease in tumor-associated macrophages in tumor-bearing mice [97]. SR8541A is another small molecule ENPP1 inhibitor which in recent in vitro studies has been shown to stimulate the migration and infiltration of peripheral blood myeloid cells into the tumor microenvironment [96]. Though the preclinical efficacy of these orally bioavailable compounds has been promising after intraperitoneal delivery, they are yet to be explored in models when delivered orally.

\subsection{Novel STING Agonists for Systemic Delivery}

Most CDN-based STING agonists in clinical development are delivered intratumorally due to their poor stability, which makes their utility limited to accessible tumors. To circumvent this, recent efforts have focused on the development of compounds that are capable of activating STING and are structurally stable for systemic delivery. A class of novel small molecule non-cyclic dinucleotides intended for systemic delivery are amidobenzimidazole (ABZI)-based compounds. One such compound, called Compound 3, was shown to activate STING and induce IFN- $\beta$ production approximately 400 -fold stronger than natural cGAMP. Intravenous administration of Compound 3, an ABZI-based compound, in the CT26 mouse model of colorectal cancer led to significant inhibition in tumor growth and improved overall survival, effects that were dependent on $\mathrm{CD} 8^{+} \mathrm{T}$ cell-mediated immune responses [111].

In a recent study, $S R-717$ was identified as a novel non-nucleotide cGAMP mimetic with potential for systemic delivery. Daily intraperitoneal injections of SR-717 to mice bearing established B16.F10 melanomas for one week resulted in a significant reduction in tumor growth and the increased survival of tumor-bearing mice [112]. Additionally, intraperitoneally administered SR-717 was shown to inhibit the formation of pulmonary nodules in a murine model of pulmonary metastasis. $M S A-2$ is another novel and orally available STING agonist with distinct structural properties that makes it stable for systemic delivery [113]. In vitro assays show that MSA-2 has a higher cellular permeability com- 
pared to other CDNs. A distinct property of MSA-2 is its binding mode which induces a closed conformation of STING, similar to the natural cGAMP ligand. Lower extracellular $\mathrm{pH}$, as seen in the acidic microenvironment of tumors, was also associated with a higher intracellular concentration of MSA-2 and greater cellular potency. Using various syngeneic murine systems including MC38 and CT26 colorectal carcinoma, B16F10 melanoma and LL-2 lung cancer models, the combination of subcutaneous or orally administered MSA-2 with intraperitoneal anti-PD1 was found to have a synergistic effect in inhibiting tumor growth and improving the overall survival of tumor-bearing mice vs. component monotherapies [113].

JNJ-'6196 has been developed as a next-generation STING agonist, which binds to STING protein with weaker affinity and a faster off rate, but is able to activate dendritic cells and induce cytokine expression with a higher potency compared to other CDNs. JNJ'6196 can be administered systemically via the intravenous route, where it has been shown to effectively eliminate bilateral tumors, promote immune-mediated resistance to tumor re-challenge, and to improve the efficacy of checkpoint inhibitors in PD-1 non-responsive tumor models in mice [91]. Further investigation into the functional properties of JNJ-'6196 showed that its systemic efficacy is related to the intensity of cytokine gene induction rather than the induced gene signature [91]. The functional efficacy of JNJ-'6196 provided via the intravenous route as well as its ability to synergize with checkpoint inhibitors make this compound an intriguing candidate for clinical development.

\section{Novel STING Agonist Delivery Platforms}

Antibody drug conjugates (ADCs) represent a novel approach for systemic yet targeted STING agonist delivery. STING antibody-drug conjugates have shown promising preclinical results [100]. In in vitro assays, STING agonist ADCs showed a 100-fold higher potency in inducing inflammatory cytokines and augmenting PBMC-mediated cancer cell death compared to free STING agonist. A single intravenous injection of targeted STING ADC in two murine tumor models led to significant inhibition in tumor growth when compared to systemically injected diABZI [100]. Interestingly, this superior anti-tumor effect was associated with significantly lower levels of systemic cytokines, supporting the ability of STING ADC to promote an effective anti-tumor response locally. XMT-2056 is the first STING ADC developed through the Immunosynthen platform that is expected to enter phase I clinical testing in 2022.

Nanoparticle (NP) vaccines or nanovaccines are a novel delivery platform that optimizes the spatiotemporal coordination of antigen presentation to APCs with innate immune responses in order to amplify the cytotoxic T cell responses [114]. PC7A NP is a synthetic nanoparticle which is shown to improve the delivery and cross-presentation of antigens by APCs, activate type I IFN genes, and stimulate specific CTL responses in mice [115]. Of note, this CTL response is independent of the toll-like receptor or MAVS pathways, but rather dependent on the activation of the CGAS/STING pathway. PC7A vaccination inhibited tumor growth in B16-F10 melanoma and MC38 colon carcinoma murine models. In addition, PC7A was shown to synergize with PD-1 inhibitor therapy, and to confer resistance against tumor development upon re-challenge, suggesting the formation of protective memory responses [115]. A study on the efficacy of liposomal nanoparticles delivering cGAMP in mice bearing basal-like triple negative breast cancer cells showed that intravenously delivered cGAMP-NPs accumulate within macrophages at the site of the tumor, skew them from M2-to-M1 inflammatory phenotype, and enhance their expression of MHC II and co-stimulatory molecules. In addition, in TNBC and B16F10 melanoma murine models with poor intrinsic response to anti-PD1 monotherapy, cGAMP-NP injection was shown to result in a more effective and durable anti-tumor response compared to soluble cGAMP [105]. ONM-500 nanovaccine was shown to effectively accumulate in lymph nodes after subcutaneous injection in mice [101]. Administration of ONM-500 containing full length E6/E7 proteins to mice bearing TC-1 cervical cancer cells resulted in a significant improvement in animal survival and was associated with long-term anti-tumor response 
in re-challenge studies. In a recent study, a novel nanovaccine with redox-responsive neoantigen-polymer conjugate and STING agonist DMXAA was developed [102]. Subcutaneous injection of this formulated nanovaccine to mice bearing B16-F10 melanoma cells in combination with anti-PD1 was found to significantly improve survival compared to non-formulated neoantigen peptides and was associated with higher systemic levels of inflammatory cytokines [102].

Antigen-presenting cell (APC)-targeted tumor vaccines are another recent development in the field of cancer therapeutics. One such formulation combining granulocyte macrophage colony stimulating factor (GCSF)-secreting pancreatic tumor cells with attenuated Listeria-expressing mesothelin has shown promising results in patients with pancreatic carcinoma [116]. A novel STING-pathway-targeting vaccine based on this platform is STINGVAX, in which synthetic CDNs are used as adjuvants and co-formulated with irradiated GCSF-expressing vaccine cells [117]. In a recent study, subcutaneous injection of STINGVAX to mice bearing B16 tumor cells was associated with STING-dependent IRF3 and type I IFN expression, and tumor regression. This anti-tumor response was amplified when STINGVAX was combined with PD-1 blocking antibody. Similar results were observed with intraperitoneal injection of STINGVAX in combination with anti-PD1 therapy in the CT26 murine model [117].

Exosomes are cell-derived nanovesicles that transmit signals and molecules between cells. In recent years, there has been an emerging interest in exosome-based therapies as a platform for delivering anti-tumor agents. In animal models, vaccination with tumorasociated exosome-loaded dendritic cells or $\mathrm{T}$ cells has been shown to enhance immune responses against tumors [118,119]. Multiple groups have recently focused on developing exosome-based therapeutics for the delivery of STING agonists to tumors. exoSTING is an engineered exosome which expresses high levels of an exosomal surface glycoprotein called Protein $\mathrm{X}$ and is loaded with a STING agonist. Intratumoral injection of exoSTING to mice bearing checkpoint refractory melanoma tumor cells results in a more potent tumor-specific immune responses and lower systemic cytokine production levels when compared to free STING administration. Combination treatment using exoSTING with PD1 checkpoint inhibitor has also been shown to further enhance anti-tumor immune responses [103].

\section{Conclusions and Future Directions}

Since the initial discovery of STING and the potency of agonizing the pathway in the pre-clinical setting, there have been accelerated attempts to develop STING agonists as effective immunotherapeutic agents. The presence of a human autoimmune phenotype (SAVI) and an ever-expanding number of pre-clinical and clinical studies support the potential for numerous STING agonist compounds in boosting anti-tumor immunity and enhancing the effects of existing immunotherapies. Despite this, there remain substantial barriers for the clinical targeting of the cGAS-STING pathway. The first-generation CDN STING agonists to enter clinical testing were administered intratumorally. This presents challenges as the approach limits the use of STING agonists to only accessible tumors. Numerous efforts are under investigation towards the development of compounds with improved properties enabling their stability for systemic delivery, with promising results obtained in pre-clinical studies implementing these compounds. Advances in imaging-guided drug delivery methods are also expected to enhance the applicability of intratumorally administered STING agonists to a wider range of tumor types. A concern raised over the systemic administration of STING agonists is whether these agents induce a state of pathologic inflammation, as the overactivation of STING has been implicated in a broad range of autoimmune conditions. The off-target effect of STING activation on other immune cells such as effector T cells could be another area of concern. In in vitro studies, STING activation was associated with the induction of stress and apoptosis in T cells [120]. Whether this would dampen T-cell-mediated responses in the clinical setting and how such effects would impact the development of memory responses need to be further explored. Few studies have suggested that certain regulatory factors are induced in response to 
cGAS-STING pathway activation, which could potentially attenuate the anti-tumor efficacy of STING agonists and lead to treatment resistance. A rapid increase in the expression of PD-L1, COX2 and IDO in the tumor microenvironment was observed after intratumoral injection of a STING agonist [121]. Using digital spatial profiling, it was also recently shown that after intratumoral injection of STING-activating nanoparticles, the expression of B7-H3 and S100A9 immune checkpoints, which are associated with tumor immune evasion is increased. Notably, this effect was partially abolished when STING-NP was used in combination with an immune checkpoint inhibitor [122]. Whether activation of the cGAS-STING pathway could elicit negative feedback loops that would dampen the effect of STING agonists is not known, and further studies are justified to determine potential mechanisms of resistance to STING agonist-based therapy. An additional limitation to the effectiveness of STING agonist therapies is the selective silencing of the cGAS-STING pathway in certain types of tumors. Indeed, the suppression of STING signaling as a result of the epigenetic silencing of promoter regions or loss-of-function mutations have been reported in tumors [123]. An improved understanding of the mechanisms underlying STING signaling defects in tumors and corrective protocols that would augment the response to STING agonists in the tumor microenvironment for therapeutic benefit is clearly warranted.

Author Contributions: Conceptualization, J.J.L.; data curation, A.A., J.J.L.; writing—original draft preparation, A.A., M.C., J.N.F.; writing - review and editing, W.J.S., J.J.L.; supervision, J.J.L.; funding acquisition, J.J.L. All authors have read and agreed to the published version of the manuscript.

Funding: Jason J. Luke acknowledges Department of Defense (W81XWH-17-1-0265), National Cancer Institute (UM1CA186690-06), Sy Holzer Endowed Immunotherapy Research Fund Award, Hillman Senior Faculty Fellow for Innovative Cancer Research.

Conflicts of Interest: A.A., None; M.C., None; J.N.F., None; W.J.S., None. J.J.L. declares Scientific Advisory Board: (no stock) 7 Hills, Spring bank (stock) Actym, Alphamab Oncology, Arch Oncology, Kanaph, Mavu, Onc.AI, Pyxis, Tempest. Consultancy with compensation: Abbvie, Array, Bayer, Bristol-Myers Squibb, Checkmate, Cstone, Eisai, EMD Serono, KSQ, Janssen, Merck, Mersana, Nektar, Novartis, Pfizer, Regeneron, Ribon, Rubius, Silicon, Tesaro, TRex, Werewolf, Xilio, Xencor. Research Support: (all to institution for clinical trials unless noted) AbbVie, Agios (IIT), Array (IIT), Astellas, Bristol-Myers Squibb (IIT and industry), Corvus, EMD Serono, Immatics, Incyte, Kadmon, Macrogenics, Merck, Moderna, Nektar, Numab, Replimmune, Rubius, Spring bank, Synlogic, Takeda, Trishula, Tizona, Xencor. Travel: Pyxis. Patents: (both provisional) Serial \#15/612,657 (Cancer Immunotherapy), PCT/US18/36052 (Microbiome Biomarkers for Anti-PD-1/PD-L1 Responsiveness: Diagnostic, Prognostic and Therapeutic Uses Thereof).

\section{References}

1. Shekarian, T.; Valsesia-Wittmann, S.; Brody, J.; Michallet, M.C.; Depil, S.; Caux, C.; Marabelle, A. Pattern recognition receptors: Immune targets to enhance cancer immunotherapy. Ann. Oncol. 2017, 28, 1756-1766. [CrossRef]

2. Kawai, T.; Akira, S. The role of pattern-recognition receptors in innate immunity: Update on toll-like receptors. Nat. Immunol. 2010, 11, 373-384. [CrossRef] [PubMed]

3. Burdette, D.L.; Monroe, K.M.; Sotelo-Troha, K.; Iwig, J.S.; Eckert, B.; Hyodo, M.; Hayakawa, Y.; Vance, R.E. STING is a direct innate immune sensor of cyclic di-GMP. Nature 2011. [CrossRef] [PubMed]

4. Zhou, L.; Zhang, Y.; Wang, Y.; Zhang, M.; Sun, W.; Dai, T.; Wang, A.; Wu, X.; Zhang, S.; Wang, S.; et al. A dual role of type I interferons in antitumor immunity. Adv. Biosyst. 2020, 1900237, 1-14. [CrossRef]

5. Zitvogel, L.; Galluzzi, L.; Kepp, O.; Smyth, M.J.; Kroemer, G. Type I interferons in anticancer immunity. Nat. Rev. Immunol. 2015, 15, 405-414. [CrossRef]

6. Hervas-Stubbs, S.; Perez-Gracia, J.L.; Rouzaut, A.; Sanmamed, M.F.; Le Bon, A.; Melero, I. Direct effects of type I interferons on cells of the immune system. Clin. Cancer Res. 2011, 17, 2619-2627. [CrossRef] [PubMed]

7. Trinchieri, G.; Santoli, D. Anti-viral activity induced by culturing lymphocytes with tumor-derived or virus-transformed cells: Enhancement of human natural killer cell activity by interferon and antagonistic inhibition of susceptibility of target cells to lysis*. J. Exp. Med. 1978. [CrossRef]

8. Lee, C.-K.; Rao, D.T.; Gertner, R.; Gimeno, R.; Frey, A.B.; Levy, D.E. Distinct requirements for IFNs and STAT1 in NK cell function. J. Immunol. 2000. [CrossRef] [PubMed] 
9. Montoya, M.; Schiavoni, G.; Mattel, F.; Gresser, I.; Belardelli, F.; Borrow, P.; Tough, D.F. Type I interferons produced by dendritic cells promote their phenotypic and functional activation. Blood 2002. [CrossRef]

10. Diamond, M.S.; Kinder, M.; Matsushita, H.; Mashayekhi, M.; Dunn, G.P.; Archambault, J.M.; Lee, H.; Arthur, C.D.; White, J.M.; Kalinke, U.; et al. Type I interferon is selectively required by dendritic cells for immune rejection of tumors. J. Exp. Med. 2011. [CrossRef]

11. Bidwell, B.N.; Slaney, C.Y.; Withana, N.P.; Forster, S.; Cao, Y.; Loi, S.; Andrews, D.; Mikeska, T.; Mangan, N.E.; Samarajiwa, S.A.; et al. Silencing of Irf7 pathways in breast cancer cells promotes bone metastasis through immune escape. Nat. Med. 2012. [CrossRef] [PubMed]

12. Von Marschall, Z.; Scholz, A.; Cramer, T.; Schäfer, G.; Schirner, M.; Öberg, K.; Wiedenmann, B.; Höcker, M.; Rosewicz, S. Effects of interferon alpha on vascular endothelial growth factor gene transcription and tumor angiogenesis. J. Natl. Cancer Inst. 2003. [CrossRef] [PubMed]

13. Ylldlrlm, C.; Nieuwenhuis, S.; Teunissen, P.F.; Horrevoets, A.J.G.; Van Royen, N.; Van Der Pouw Kraan, T.C.T.M. Interferon-beta, a decisive factor in angiogenesis and arteriogenesis. J. Interf. Cytokine Res. 2015, 35, 411-420.

14. Ishikawa, H.; Ma, Z.; Barber, G.N. STING regulates intracellular DNA-mediated, type i interferon-dependent innate immunity. Nature 2009. [CrossRef] [PubMed]

15. Chen, Q.; Sun, L.; Chen, Z.J. Regulation and function of the cGAS-STING pathway of cytosolic DNA sensing. Nat. Immunol. 2016, 17, 1142-1149. [CrossRef] [PubMed]

16. Woo, S.R.; Fuertes, M.B.; Corrales, L.; Spranger, S.; Furdyna, M.J.; Leung, M.Y.K.; Duggan, R.; Wang, Y.; Barber, G.N.; Fitzgerald, K.A.; et al. STING-dependent cytosolic DNA sensing mediates innate immune recognition of immunogenic tumors. Immunity 2014, 41, 830-842. [CrossRef] [PubMed]

17. Liu, Y.; Jesus, A.A.; Marrero, B.; Yang, D.; Ramsey, S.E.; Montealegre Sanchez, G.A.; Tenbrock, K.; Wittkowski, H.; Jones, O.Y.; Kuehn, H.S.; et al. Activated STING in a vascular and pulmonary syndrome. N. Engl. J. Med. 2014. [CrossRef]

18. Clarke, S.L.N.; Pellowe, E.J.; De Jesus, A.A.; Goldbach-Mansky, R.; Hilliard, T.N.; Ramanan, A.V. Interstitial lung disease caused by STING-associated vasculopathy with onset in infancy. Am. J. Respir. Crit. Care Med. 2016, 194, 639-642. [CrossRef] [PubMed]

19. Konno, H.; Chinn, I.K.; Hong, D.; Orange, J.S.; Lupski, J.R.; Mendoza, A.; Pedroza, L.A.; Barber, G.N. Pro-inflammation associated with a gain-of-function mutation (R284S) in the innate immune sensor STING. Cell Rep. 2018. [CrossRef]

20. König, N.; Fiehn, C.; Wolf, C.; Schuster, M.; Cura Costa, E.; Tüngler, V.; Alvarez, H.A.; Chara, O.; Engel, K.; Goldbach-Mansky, R.; et al. Familial chilblain lupus due to a gain-of-function mutation in STING. Ann. Rheum. Dis. 2017. [CrossRef]

21. Hoeijmakers, J.H.J. Genome maintenance mechanisms for preventing cancer. Nature 2001, 411, 366-374. [CrossRef]

22. Kiwerska, K.; Szyfter, K. DNA repair in cancer initiation, progression, and therapy-A double-edged sword. J. Appl. Genet. 2019, 60, 329-334. [CrossRef] [PubMed]

23. Bhattacharya, S.; Srinivasan, K.; Abdisalaam, S.; Su, F.; Raj, P.; Dozmorov, I.; Mishra, R.; Wakeland, E.K.; Ghose, S.; Mukherjee, S.; et al. RAD51 interconnects between DNA replication, DNA repair and immunity. Nucleic Acids Res. 2017. [CrossRef] [PubMed]

24. Guan, J.; Lu, C.; Jin, Q.; Lu, H.; Chen, X.; Tian, L.; Zhang, Y.; Ortega, J.; Zhang, J.; Siteni, S.; et al. MLH1 deficiency-triggered DNA hyperexcision by exonuclease 1 activates the cGAS-STING pathway. Cancer Cell 2021. [CrossRef]

25. Talens, F.; Van Vugt, M.A.T.M. Inflammatory signaling in genomically instable cancers. Cell Cycle 2019, 18, 1830-1848. [CrossRef]

26. He, L.; Xiao, X.; Yang, X.; Zhang, Z.; Wu, L.; Liu, Z. STING signaling in tumorigenesis and cancer therapy: A friend or foe? Cancer Lett. 2017, 402, 203-212. [CrossRef] [PubMed]

27. Reisländer, T.; Groelly, F.J.; Tarsounas, M. DNA damage and cancer immunotherapy: A STING in the tale. Mol. Cell 2020, 80, 21-28. [CrossRef]

28. Campisi, M.; Sundararaman, S.K.; Shelton, S.E.; Knelson, E.H.; Mahadevan, N.R.; Yoshida, R.; Tani, T.; Ivanova, E.; Cañadas, I.; Osaki, T.; et al. Tumor-derived cGAMP regulates activation of the vasculature. Front. Immunol. 2020. [CrossRef]

29. Schadt, L.; Sparano, C.; Schweiger, N.A.; Silina, K.; Cecconi, V.; Lucchiari, G.; Yagita, H.; Guggisberg, E.; Saba, S.; Nascakova, Z.; et al. Cancer-cell-intrinsic cGAS expression mediates tumor immunogenicity. Cell Rep. 2019. [CrossRef]

30. Andzinski, L.; Spanier, J.; Kasnitz, N.; Kröger, A.; Jin, L.; Brinkmann, M.M.; Kalinke, U.; Weiss, S.; Jablonska, J.; Lienenklaus, S. Growing tumors induce a local STING dependent type I IFN response in dendritic cells. Int. J. Cancer 2016. [CrossRef] [PubMed]

31. Yang, H.; Lee, W.S.; Kong, S.J.; Kim, C.G.; Kim, J.H.; Chang, S.K.; Kim, S.; Kim, G.; Chon, H.J.; Kim, C. STING activation reprograms tumor vasculatures and synergizes with VEGFR2 blockade. J. Clin. Invest. 2019. [CrossRef]

32. Chelvanambi, M.; Fecek, R.J.; Taylor, J.L.; Storkus, W.J. STING agonist-based treatment promotes vascular normalization and tertiary lymphoid structure formation in the therapeutic melanoma microenvironment. J. Immunother. Cancer 2021. [CrossRef] [PubMed]

33. Samstein, R.M.; Lee, C.H.; Shoushtari, A.N.; Hellmann, M.D.; Shen, R.; Janjigian, Y.Y.; Barron, D.A.; Zehir, A.; Jordan, E.J.; Omuro, A.; et al. Tumor mutational load predicts survival after immunotherapy across multiple cancer types. Nat. Genet. 2019, 51, 202-206. [CrossRef] [PubMed]

34. Goodman, A.M.; Kato, S.; Bazhenova, L.; Patel, S.P.; Frampton, G.M.; Miller, V.; Stephens, P.J.; Daniels, G.A.; Kurzrock, R. Tumor mutational burden as an independent predictor of response to immunotherapy in diverse cancers. Mol. Cancer Ther. 2017. [CrossRef]

35. Daei Farshchi Adli, A.; Jahanban-Esfahlan, R.; Seidi, K.; Samandari-Rad, S.; Zarghami, N. An overview on Vadimezan (DMXAA): The vascular disrupting agent. Chem. Biol. Drug Des. 2018, 91, 996-1006. [CrossRef] 
36. Baguley, B.C. Antivascular therapy of cancer: DMXAA. Lancet Oncol. 2003, 4, 141-1148. [CrossRef]

37. Howe, F.A.; McPhail, L.D.; Griffiths, J.R.; McIntyre, D.J.O.; Robinson, S.P. Vessel size index magnetic resonance imaging to monitor the effect of antivascular treatment in a rodent tumor model. Int. J. Radiat. Oncol. Biol. Phys. 2008. [CrossRef] [PubMed]

38. Matthews, K.E.; Hermans, I.F.; Roberts, J.M.; Ching, L.M.; Ronchese, F. 5,6-Dimethylxanthenone-4-acetic acid treatment of a non-immunogenic tumour does not synergize with active or passive CD8+ T-cell immunotherapy. Immunol. Cell Biol. 2006. [CrossRef]

39. Lemos, H.; Mohamed, E.; Huang, L.; Ou, R.; Pacholczyk, G.; Arbab, A.S.; Munn, D.; Mellor, A.L. STING promotes the growth of tumors characterized by low antigenicity via IDO activation. Cancer Res. 2016. [CrossRef]

40. Gulen, M.F.; Koch, U.; Haag, S.M.; Schuler, F.; Apetoh, L.; Villunger, A.; Radtke, F.; Ablasser, A. Signalling strength determines proapoptotic functions of STING. Nat. Commun. 2017. [CrossRef]

41. Huang, Y.; Goel, S.; Duda, D.G.; Fukumura, D.; Jain, R.K. Vascular normalization as an emerging strategy to enhance cancer immunotherapy. Cancer Res. 2013, 73, 2943-2948. [CrossRef] [PubMed]

42. Martin, J.D.; Seano, G.; Jain, R.K. Normalizing function of tumor vessels: Progress, opportunities, and challenges. Annu. Rev. Physiol. 2019, 81, 505-534. [CrossRef]

43. Bose, A.; Taylor, J.L.; Alber, S.; Watkins, S.C.; Garcia, J.A.; Rini, B.I.; Ko, J.S.; Cohen, P.A.; Finke, J.H.; Storkus, W.J. Sunitinib facilitates the activation and recruitment of therapeutic anti-tumor immunity in concert with specific vaccination. Int. J. Cancer 2011. [CrossRef] [PubMed]

44. Downey, C.M.; Aghaei, M.; Schwendener, R.A.; Jirik, F.R. DMXAA causes tumor site-specific vascular disruption in murine non-small cell lung cancer, and like the endogenous non-canonical cyclic dinucleotide STING agonist, $2^{\prime} 3^{\prime}$-cGAMP, induces M2 macrophage repolarization. PLOS ONE 2014. [CrossRef]

45. Demaria, O.; De Gassart, A.; Coso, S.; Gestermann, N.; Di Domizio, J.; Flatz, L.; Gaide, O.; Michielin, O.; Hwu, P.; Petrova, T.V.; et al. STING activation of tumor endothelial cells initiates spontaneous and therapeutic antitumor immunity. Proc. Natl. Acad. Sci. USA 2015. [CrossRef] [PubMed]

46. Pipi, E.; Nayar, S.; Gardner, D.H.; Colafrancesco, S.; Smith, C.; Barone, F. Tertiary lymphoid structures: Autoimmunity goes local. Front. Immunol. 2018, 9, 1952. [CrossRef] [PubMed]

47. Dieu-Nosjean, M.C.; Goc, J.; Giraldo, N.A.; Sautès-Fridman, C.; Fridman, W.H. Tertiary lymphoid structures in cancer and beyond. Trends Immunol. 2014, 35, 571-580. [CrossRef] [PubMed]

48. Neyt, K.; Perros, F.; GeurtsvanKessel, C.H.; Hammad, H.; Lambrecht, B.N. Tertiary lymphoid organs in infection and autoimmunity. Trends Immunol. 2012, 33, 297-305. [CrossRef]

49. Weinstein, A.M.; Storkus, W.J. Biosynthesis and functional significance of peripheral node addressin in cancer-associated TLO. Front. Immunol. 2016, 7, 301. [CrossRef]

50. Jones, E.; Gallimore, A.; Ager, A. Defining high endothelial venules and tertiary lymphoid structures in cancer. In Methods in Molecular Biology; Humana Press: Totowa, NJ, USA, 2018.

51. Denton, A.E.; Innocentin, S.; Carr, E.J.; Bradford, B.M.; Lafouresse, F.; Mabbott, N.A.; Mörbe, U.; Ludewig, B.; Groom, J.R.; Good-Jacobson, K.L.; et al. Type I interferon induces CXCL13 to support ectopic germinal center formation. J. Exp. Med. 2019. [CrossRef]

52. Cufi, P.; Dragin, N.; Ruhlmann, N.; Weiss, J.M.; Fadel, E.; Serraf, A.; Berrih-Aknin, S.; Le Panse, R. Central role of interferon-beta in thymic events leading to myasthenia gravis. J. Autoimmun. 2014. [CrossRef]

53. Martinet, L.; Le Guellec, S.; Filleron, T.; Lamant, L.; Meyer, N.; Rochaix, P.; Garrido, I.; Girard, J.P. High endothelial venules (HEVs) in human melanoma lesions: Major gateways for tumor-infiltrating lymphocytes. Oncoimmunology 2012. [CrossRef]

54. Kuerten, S.; Schickel, A.; Kerkloh, C.; Recks, M.S.; Addicks, K.; Ruddle, N.H.; Lehmann, P.V. Tertiary lymphoid organ development coincides with determinant spreading of the myelin-specific T cell response. Acta Neuropathol. 2012. [CrossRef] [PubMed]

55. Lehmann-Horn, K.; Wang, S.; Sagan, S.A.; Zamvil, S.S.; von Büdingen, H.-C. B cell repertoire expansion occurs in meningeal ectopic lymphoid tissue. JCI Insight 2016. [CrossRef] [PubMed]

56. Kuwabara, S.; Tsuchikawa, T.; Nakamura, T.; Hatanaka, Y.; Hatanaka, K.C.; Sasaki, K.; Ono, M.; Umemoto, K.; Suzuki, T.; Sato, O.; et al. Prognostic relevance of tertiary lymphoid organs following neoadjuvant chemoradiotherapy in pancreatic ductal adenocarcinoma. Cancer Sci. 2019. [CrossRef]

57. Sakimura, C.; Tanaka, H.; Okuno, T.; Hiramatsu, S.; Muguruma, K.; Hirakawa, K.; Wanibuchi, H.; Ohira, M. B cells in tertiary lymphoid structures are associated with favorable prognosis in gastric cancer. J. Surg. Res. 2017. [CrossRef]

58. Cabrita, R.; Lauss, M.; Sanna, A.; Donia, M.; Skaarup Larsen, M.; Mitra, S.; Johansson, I.; Phung, B.; Harbst, K.; Vallon-Christersson, J.; et al. Tertiary lymphoid structures improve immunotherapy and survival in melanoma. Nature 2020. [CrossRef]

59. Helmink, B.A.; Reddy, S.M.; Gao, J.; Zhang, S.; Basar, R.; Thakur, R.; Yizhak, K.; Sade-Feldman, M.; Blando, J.; Han, G.; et al. B cells and tertiary lymphoid structures promote immunotherapy response. Nature 2020. [CrossRef] [PubMed]

60. Avram, G.; Sánchez-Sendra, B.; Martín, J.M.; Terrádez, L.; Ramos, D.; Monteagudo, C. The density and type of MECA-79positive high endothelial venules correlate with lymphocytic infiltration and tumour regression in primary cutaneous melanoma. Histopathology 2013. [CrossRef]

61. Messina, J.L.; Fenstermacher, D.A.; Eschrich, S.; Qu, X.; Berglund, A.E.; Lloyd, M.C.; Schell, M.J.; Sondak, V.K.; Weber, J.S.; Mulé, J.J. 12-chemokine gene signature identifies lymph node-like structures in melanoma: Potential for patient selection for immunotherapy? Sci. Rep. 2012. [CrossRef] 
62. Wang, F.; Su, H.; Xu, D.; Dai, W.; Zhang, W.; Wang, Z.; Anderson, C.F.; Zheng, M.; Oh, R.; Wan, F.; et al. Tumour sensitization via the extended intratumoural release of a STING agonist and camptothecin from a self-assembled hydrogel. Nat. Biomed. Eng. 2020. [CrossRef]

63. Junkins, R.D.; Gallovic, M.D.; Johnson, B.M.; Collier, M.A.; Watkins-Schulz, R.; Cheng, N.; David, C.N.; McGee, C.E.; Sempowski, G.D.; Shterev, I.; et al. A robust microparticle platform for a STING-targeted adjuvant that enhances both humoral and cellular immunity during vaccination. J. Control. Release 2018. [CrossRef]

64. McKeage, M.J.; Von Pawel, J.; Reck, M.; Jameson, M.B.; Rosenthal, M.A.; Sullivan, R.; Gibbs, D.; Mainwaring, P.N.; Serke, M.; Lafitte, J.J.; et al. Randomised phase II study of ASA404 combined with carboplatin and paclitaxel in previously untreated advanced non-small cell lung cancer. Br. J. Cancer 2008. [CrossRef] [PubMed]

65. Lara, P.N.; Douillard, J.Y.; Nakagawa, K.; Von Pawel, J.; McKeage, M.J.; Albert, I.; Losonczy, G.; Reck, M.; Heo, D.S.; Fan, X.; et al. Randomized phase III placebo-controlled trial of carboplatin and paclitaxel with or without the vascular disrupting agent vadimezan (ASA404) in advanced non-small-cell lung cancer. J. Clin. Oncol. 2011. [CrossRef]

66. Corrales, L.; Glickman, L.H.; McWhirter, S.M.; Kanne, D.B.; Sivick, K.E.; Katibah, G.E.; Woo, S.R.; Lemmens, E.; Banda, T.; Leong, J.J.; et al. Direct activation of STING in the tumor microenvironment leads to potent and systemic tumor regression and immunity. Cell Rep. 2015, 11, 1018-1030. [CrossRef] [PubMed]

67. Kanwar, J.R.; Kanwar, R.K.; Pandey, S.; Ching, L.M.; Krissansen, G.W. Vascular attack by 5,6-dimethylxanthenone-4-acetic acid combined with B7.1 (CD80)-mediated immunotherapy overcomes immune resistance and leads to the eradication of large tumors and multiple tumor foci. Cancer Res. 2001, 61, 1948-1956. [PubMed]

68. Shih, A.Y.; Damm-Ganamet, K.L.; Mirzadegan, T. Dynamic structural differences between human and mouse STING lead to differing sensitivity to DMXAA. Biophys. J. 2018. [CrossRef] [PubMed]

69. Sivick, K.E.; Desbien, A.L.; Glickman, L.H.; Reiner, G.L.; Corrales, L.; Surh, N.H.; Hudson, T.E.; Vu, U.T.; Francica, B.J.; Banda, T.; et al. Magnitude of therapeutic STING activation determines CD8+ T cell-mediated anti-tumor immunity. Cell Rep. 2018. [CrossRef]

70. Francica, B.J.; Ghasemzadeh, A.; Desbien, A.L.; Theodros, D.; Sivick, K.E.; Reiner, G.L.; Glickman, L.H.; Marciscano, A.E.; Sharabi, A.B.; Leong, M.L.; et al. TNFa and radioresistant stromal cells are essential for therapeutic efficacy of cyclic dinucleotide STING agonists in nonimmunogenic tumors. Cancer Immunol. Res. 2018. [CrossRef]

71. Foote, J.B.; Kok, M.; Leatherman, J.M.; Armstrong, T.D.; Marcinkowski, B.C.; Ojalvo, L.S.; Kanne, D.B.; Jaffee, E.M.; Dubensky, T.W.; Emens, L.A. A STING agonist given with OX40 receptor and PD-L1 modulators primes immunity and reduces tumor growth in tolerized mice. Cancer Immunol. Res. 2017. [CrossRef]

72. Deng, W.; Desbien, A.L.; Gauthier, K.S.; Reiner, G.; Corrales, L.; Schroeder, T.; Glickman, L.H.; Surh, N.H.; Francica, B.; Leong, J.J.; et al. Abstract P351: ADU-S100 (MIW815) synergizes with checkpoint inhibition to elicit an anti-tumor CD8+ T cell response to control distal tumors. In Proceedings of the Society for Immunotherapy of Cancer 33rd Annual Meeting, Washington, DC, USA, 7-11 November 2018.

73. Meric-Bernstam, F.; Sandhu, S.K.; Hamid, O.; Spreafico, A.; Kasper, S.; Dummer, R.; Shimizu, T.; Steeghs, N.; Lewis, N.; Talluto, C.C.; et al. Phase Ib study of MIW815 (ADU-S100) in combination with spartalizumab (PDR001) in patients (pts) with advanced/metastatic solid tumors or lymphomas. J. Clin. Oncol. 2019. [CrossRef]

74. Harrington, K.J.; Brody, J.; Ingham, M.; Strauss, J.; Cemerski, S.; Wang, M.; Tse, A.; Khilnani, A.; Marabelle, A.; Golan, T. Preliminary results of the first-in-human (FIH) study of MK-1454, an agonist of stimulator of interferon genes (STING), as monotherapy or in combination with pembrolizumab (pembro) in patients with advanced solid tumors or lymphomas. Ann. Oncol. 2018. [CrossRef]

75. Challa, S.V.; Zhou, S.; Sheri, A.; Padmanabhan, S.; Meher, G.; Gimi, R.; Schmidt, D.; Cleary, D.; Afdhal, N.; Iyer, R. Preclinical studies of SB 11285, a novel STING agonist for immuno-oncology. J. Clin. Oncol. 2017. [CrossRef]

76. Schieven, G.; Brown, J.; Swanson, J.; Stromko, C.; Ho, C.-P.; Zhang, R.; Li-Wang, B.; Qiu, H.; Sun, H.; Fink, B.; et al. Abstract P525: Preclinical characterization of BMS-986301, a differentiated STING agonist with robust antitumor activity as monotherapy or in combination with anti-PD-1. In Proceedings of the Society for Immunotherapy of Cancer 33rd Annual Meeting, Washington, DC, USA, 7-11 November 2018.

77. Gremel, G.; Impagnatiello, M.A.; Carotta, S.; Schaaf, O.; Chetta, P.M.; Oost, T.; Zichner, T.; Hofmann, M.; Blake, S.; Bretschneider, T.; et al. Abstract 4522: Potent induction of a tumor-specific immune response by a cyclic dinucleotide STING agonist. Am. Assoc. Cancer Res. 2020, 80, 4522.

78. ENDO, A.; Kim, D.-S.; Huang, K.-C.; Hao, M.-H.; Mathieu, S.; Choi, H.; Majumder, U.; Zhu, X.; Shen, Y.; Sanders, K.; et al. Abstract 4456: Discovery of E7766: A representative of a novel class of macrocycle-bridged STING agonists (MBSAs) with superior potency and pan-genotypic activity. Am. Assoc. Cancer Res. 2019, 79, 4456.

79. Huang, K.-C.; Endo, A.; McGrath, S.; Chandra, D.; Wu, J.; Kim, D.-S.; Albu, D.; Ingersoll, C.; Tendyke, K.; Loiacono, K.; et al. Abstract 3269: Discovery and characterization of E7766, a novel macrocycle-bridged STING agonist with pan-genotypic and potent antitumor activity through intravesical and intratumoral administration. Am. Assoc. Cancer Res. 2019, $79,3269$.

80. Huang, K.-C.; Zhang, C.; Yu, K.; Kim, D.-S.; Dixit, V.; Hukkanen, R.; Choi, H.-W.; Hutz, J.; Fang, F.; Bao, X. Abstract 592: Demonstration of E7766, a novel STING agonist, as a potent immunotherapy in BCG-insensitive non-muscle invasive bladder cancer models via intravesical administration. Am. Assoc. Cancer Res. 2020, 80, 592. 
81. Leventhal, D.S.; Sokolovska, A.; Li, N.; Plescia, C.; Kolodziej, S.A.; Gallant, C.W.; Christmas, R.; Gao, J.R.; James, M.J.; AbinFuentes, A.; et al. Immunotherapy with engineered bacteria by targeting the STING pathway for anti-tumor immunity. Nat. Commun. 2020. [CrossRef] [PubMed]

82. Glickman, L.H.; Skoble, J.; Rae, C.S.; Makarova, A.M.; D'Antonio, M.A.; McGeehan, A.J.; Thanos, C. Abstract P235: STACT-TREX1: A novel tumor-targeting systemically-delivered STING pathway agonist demonstrates robust anti-tumor efficacy in multiple murine cancer models. In Proceedings of the Society for Immunotherapy of Cancer 33rd Annual Meeting, Washington, DC, USA, 7-11 November 2018.

83. Makarova, A.M.; Iannello, A.; Rae, C.S.; King, B.; Besprozvannaya, M.; Faulhaber, J.; Skoble, J.; Thanos, C.D.; Glickman, L.H. Abstract 5016: STACT-TREX1: A systemically-administered STING pathway agonist targets tumor-resident myeloid cells and induces adaptive anti-tumor immunity in multiple preclinical models. Am. Assoc. Cancer Res. 2019, 79, 5016.

84. Smith, M.; Chin, D.; Chan, S.; Mahady, S.; Campion, L.; Morgan, C.; Patel, S.; Chu, G.; Hughes, A.; Bignan, G.; et al. Abstract 5567: In vivo administration of the STING agonist, JNJ-67544412, leads to complete regression of established murine subcutaneous tumors. Am. Assoc. Cancer Res. 2020, 80, 5567.

85. Thomsen, M.K. Abstract 2344: The cGAS-STING pathway is a therapeutic target in a preclinical model of hepatocellular carcinoma. Oncogene 2019, 39, 1652-1664. [CrossRef] [PubMed]

86. Yang, J.; Adam, M.; Clemens, J.; Creech, K.; Schneck, J.; Pasikanti, K.; Tran, J.-L.; Joglekar, D.; Hopson, C.; Pesiridis, S.; et al. Abstract 5554: Preclinical characterization of GSK532, a novel STING agonist with potent anti-tumor activity. Am. Assoc. Cancer Res. 2018, 78, 5554.

87. Chmielewski, S.; Zawadzka, M.; Mazurek, J.; Rogacki, M.K.; Gluza, K.; Wójcik-Jaszczyńska, K.; Poczkaj, A.; Ćwiertnia, G.; Topolnicki, G.; Kujawa, M.; et al. Abstract 4532A: Development of selective small molecule STING agonists suitable for systemic administration. Am. Assoc. Cancer Res. 2020, 80, 5432A.

88. Binder, G.A.; Gambino, C.S.; Kharitonova, A.; Metcalf, R.S.; Daniel, K.G.; Guida, W.C. Abstract 6: Computationally assisted target screening of STING agonist for immunologic therapy. Am. Assoc. Cancer Res. 2019, 79, 6.

89. Dobrzańska, M.; Chmielewski, S.; Zawadzka, M.; Mazurek, J.; Gluza, K.; Wójcik-Jaszczyńska, K.; Kujawa, M.; Topolnicki, G.; Ćwiertnia, G.; Poczkaj, A.; et al. Abstract 4983: Discovery and characterization of next-generation small molecule direct STING agonists. Am. Assoc. Cancer Res. 2019, 79, 4983.

90. Wang, Z.; Dove, P.; Rosa, D.; Bossen, B.; Helke, S.; Charbonneau, M.; Brinen, L.; Dodge, K.; Lin, G.H.; Galligan, C.; et al. Abstract 3854: Preclinical characterization of a novel non-cyclic dinucleotide small molecule STING agonist with potent antitumor activity in mice. Am. Assoc. Cancer Res. 2019, 79, 3854.

91. Chan, S.R.; Bignan, G.; Pierson, E.; Mahady, S.; Ta, H.; Schepens, W.; Thuring, J.W.; Lim, H.K.; Otieno, M.; Wilde, T.; et al. Abstract 5567A: JNJ-'6196: A next generation STING agonist with potent preclinical activity by the IV route. Am. Assoc. Cancer Res. 2020, $80,5567 \mathrm{~A}$.

92. Banerjee, M.; Basu, S.; Middya, S.; Shrivastava, R.; Ghosh, R.; Pryde, D.C.; Yadav, D.; Bhattacharya, G.; Soram, T.; Puniya, K.; et al. Abstract LB-061: CRD5500: A versatile small molecule STING agonist amenable to bioconjugation as an ADC. Am. Assoc. Cancer Res. 2019, 79, LB-061.

93. Li, A.; Song, Y.; Dong, C.; Chen, X.; Yang, J. Abstract 3317: Discovery of novel STING agonists with robust anti-tumor activity. Am. Assoc. Cancer Res. 2020, 80, 3317.

94. Perera, S.A.; Kopinja, J.E.; Ma, Y.; Laskey, J.; Chakravarthy, K.; Chen, Y.; Cui, L.; Presland, J.; Zhao, S.; Minnihan, E.; et al. Abstract 4721: Combining STING agonists with an anti-PD-1 antagonist results in marked antitumor activity in immune-excluded tumors. Am. Assoc. Cancer Res. 2018, 78, 4721.

95. Jekle, A.; Thatikonda, S.; Stevens, S.; Williams, C.; Kinkade, A.; Ren, S.; Jaisinghani, R.; Zhang, Q.; Misner, D.; Stoycheva, A.; et al. Abstract 4520: Preclinical characterization of ALG-031048, a novel STING agonist with potent anti-tumor activity in mice. Am. Assoc. Cancer Res. 2020, 80, 4520.

96. Weston, A.S.; Thode, T.G.; Rodriguez del Villar, R.; Dana, S.; Kasibhatla, S.; Kaadige, M.R.; Sharma, S. Abstract LB-118: SR8541A is a potent inhibitor of ENPP1 and exhibits dendritic cell mediated antitumor activity. Cancer Res. 2020, 80 (Suppl. 16). [CrossRef]

97. Weston, A.; Thode, T.; Munoz, R.; Daniel, S.; Soldi, R.; Kaadige, M.; Han, H.; Vankayalapti, H.; Sharma, S. Abstract 3077: Preclinical studies of SR-8314, a highly selective ENPP1 inhibitor and an activator of STING pathway. Am. Assoc. Cancer Res. 2019, 79, 3077.

98. Sharma, S.; Weston, A.; Thode, T.; Gomez, E.; Kaadige, M.; Vankayalapti, H. Abstract 1932: Discovery of ENPP1 inhibitors as agonists of STING pathway. Am. Assoc. Cancer Res. 2018, 78, 1932.

99. Baird, J.; Dietsch, G.; Florio, V.; Gallatin, M.; Knox, C. MV-626, a potent and selective inhibitor of ENPP1 enhances STING activation and augments T-cell mediated anti-tumor activity in vivo. In Proceedings of the Poster presented at Society for Immunotherapy of Cancer Annual Meeting, Washington, DC, USA, 7-11 November 2018; Available online: https://digitalcommons.psjhealth org/sitc2018/7 (accessed on 29 May 2021).

100. Bukhalid, R.A.; Duvall, J.R.; Cetinbas, N.M.; Catcott, K.C.; Avocetien, K.; Bentley, K.W.; Bradley, S.; Carter, T.; Chin, C.-N.; Clardy, S.; et al. Abstract 6706: Systemic Administration of STING Agonist Antibody-Drug Conjugates Elicit Potent Anti-Tumor Immune Responses with Minimal Induction of Circulating Cytokines. Cancer Res. 2020, 80 (Suppl. 16). [CrossRef] 
101. Miller, J.; Luo, M.; Wang, H.; Wang, Z.; Ding, X.; Campbell, A.; Almazan, J.; Gutowski, S.; Chen, Z.; Gao, J.; et al. Abstract 4577: ONM-500: A STING-activating therapeutic nanovaccine platform for cancer immunotherapy. Am. Assoc. Cancer Res. 2020, 80, 4577.

102. Mi, Y.; Smith, C.C.; Serody, J.S.; Vincent, B.G.; Wang, A.Z.; Hyun, H. Abstract 2866: Neoantigen nanovaccine improves personalized cancer immunotherapy. Am. Assoc. Cancer Res. 2020, 80, 2866.

103. Jang, S.C.; Moniz, R.J.; Sia, C.L.; Harrison, R.A.; Houde, D.; Ross, N.; Xu, K.; Lewis, N.; Bourdeau, R.; McCoy, C.; et al. Abstract 944: ExoSTING: An engineered exosome therapeutic that selectively delivers STING agonist to the tumor resident antigen-presenting cells resulting in improved tumor antigen-specific adaptive immune response. Am. Assoc. Cancer Res. 2019, 79, 94.

104. Jang, S.C.; Moniz, R.J.; Sia, C.; Dey, J. Abstract P618: Selective delivery of exosome-mediated STING agonist to antigen presenting cells results in significantly improved potency and reduced toxicity. In Proceedings of the Society for Immunotherapy of Cancer 33rd Annual Meeting, Washington, DC, USA, 7-11 November 2018.

105. Cheng, N.; Watkins-Schulz, R.; Junkins, R.; David, C.; Johnson, B.M.; Montgomery, S.A.; Peine, K.J.; Darr, D.B.; Yuan, H.; McKinnon, K.P.; et al. Abstract LB-126: Nanoparticle-incorporated STING activator as an immunotherapeutic for PD-L1 resistant triple-negative breast cancer. Am. Assoc. Cancer Res. 2018, 78, LB-126.

106. Thomsen, M.K.; Skouboe, M.K.; Boularan, C.; Vernejoul, F.; Lioux, T.; Leknes, S.L.; Berthelsen, M.F.; Riedel, M.; Cai, H.; Joseph, J.V.; et al. The cGAS-STING pathway is a therapeutic target in a preclinical model of hepatocellular carcinoma. Oncogene 2020. [CrossRef]

107. Jekle, A.; Thatikonda, S.; Jaisinghani, R.; Ren, S. Tumor regression in a mouse model of hepatocellular carcinoma upon treatment with the STING agonist ALG-031048. In Proceedings of the American Association for the Study of Liver Diseases Annual Meeting; 2020. (virtual). Available online: https:/ /www.aligos.com/wp-content/uploads/2020/11/Tumor-regression-in-a-mouse-modelof-hepatocellular-carcinoma-upon-treatment-with-the-STING-agonist-ALG-031048.pdf (accessed on 29 May 2021).

108. Onyedibe, K.I.; Wang, M.; Sintim, H.O. ENPP1, an old enzyme with new functions, and small molecule inhibitors-A sting in the tale of ENPP1. Molecules 2019, 24, 4192. [CrossRef] [PubMed]

109. Kato, K.; Nishimasu, H.; Oikawa, D.; Hirano, S.; Hirano, H.; Kasuya, G.; Ishitani, R.; Tokunaga, F.; Nureki, O. Structural insights into cGAMP degradation by Ecto-nucleotide pyrophosphatase phosphodiesterase 1. Nat. Commun. 2018. [CrossRef] [PubMed]

110. Li, L.; Yin, Q.; Kuss, P.; Maliga, Z.; Millán, J.L.; Wu, H.; Mitchison, T.J. Hydrolysis of 2'3'-cGAMP by ENPP1 and design of nonhydrolyzable analogs. Nat. Chem. Biol. 2014. [CrossRef]

111. Ramanjulu, J.M.; Pesiridis, G.S.; Yang, J.; Concha, N.; Singhaus, R.; Zhang, S.Y.; Tran, J.L.; Moore, P.; Lehmann, S.; Eberl, H.C.; et al. Design of amidobenzimidazole STING receptor agonists with systemic activity. Nature 2018. [CrossRef] [PubMed]

112. Chin, E.N.; Yu, C.; Vartabedian, V.F.; Jia, Y.; Kumar, M.; Gamo, A.M.; Vernier, W.; Ali, S.H.; Kissai, M.; Lazar, D.C.; et al. Antitumor activity of a systemic STING-activating non-nucleotide cGAMP mimetic. Science 2020. [CrossRef] [PubMed]

113. Pan, B.S.; Perera, S.A.; Piesvaux, J.A.; Presland, J.P.; Schroeder, G.K.; Cumming, J.N.; Wesley Trotter, B.; Altman, M.D.; Buevich, A.V.; Cash, B.; et al. An orally available non-nucleotide STING agonist with antitumor activity. Science 2020. [CrossRef] [PubMed]

114. Zhang, Y.; Lin, S.; Wang, X.Y.; Zhu, G. Nanovaccines for cancer immunotherapy. Wiley Interdiscip. Rev. Nanomed. Nanobiotechnology 2019, 11, 1-29. [CrossRef]

115. Luo, M.; Wang, H.; Wang, Z.; Cai, H.; Lu, Z.; Li, Y.; Du, M.; Huang, G.; Wang, C.; Chen, X.; et al. A STING-activating nanovaccine for cancer immunotherapy. Nat. Nanotechnol. 2017. [CrossRef]

116. Le, D.T.; Wang-Gillam, A.; Picozzi, V.; Greten, T.F.; Crocenzi, T.; Springett, G.; Morse, M.; Zeh, H.; Cohen, D.; Fine, R.L.; et al. Safety and survival with GVAX pancreas prime and listeria monocytogenes-expressing mesothelin (CRS-207) boost vaccines for metastatic pancreatic cancer. J. Clin. Oncol. 2015. [CrossRef] [PubMed]

117. Fu, J.; Kanne, D.B.; Leong, M.; Glickman, L.H.; McWhirter, S.M.; Lemmens, E.; Mechette, K.; Leong, J.J.; Lauer, P.; Liu, W.; et al. STING agonist formulated cancer vaccines can cure established tumors resistant to PD-1 blockade. Sci. Transl. Med. 2015. [CrossRef]

118. Xie, Y.; Wang, L.; Freywald, A.; Qureshi, M.; Chen, Y.; Xiang, J. A novel T cell-based vaccine capable of stimulating long-term functional CTL memory against B16 melanoma via CD40L signaling. Cell. Mol. Immunol. 2013. [CrossRef]

119. Xiao, L.; Erb, U.; Zhao, K.; Hackert, T.; Zöller, M. Efficacy of vaccination with tumor-exosome loaded dendritic cells combined with cytotoxic drug treatment in pancreatic cancer. Oncoimmunology 2017. [CrossRef] [PubMed]

120. Larkin, B.; Ilyukha, V.; Sorokin, M.; Buzdin, A.; Vannier, E.; Poltorak, A. Cutting edge: Activation of STING in T cells induces type I IFN responses and cell death. J. Immunol. 2017. [CrossRef]

121. Lemos, H.; Ou, R.; McCardle, C.; Lin, Y.; Calver, J.; Minett, J.; Chadli, A.; Huang, L.; Mellor, A.L. Overcoming resistance to STING agonist therapy to incite durable protective antitumor immunity. J. Immunother. Cancer 2020. [CrossRef] [PubMed]

122. Wilson, J.T.; Shae, D.; Gonzalez-Ericsson, P.I.; Sanchez, V.; Gong, J.; Liang, Y.; Hinerfeld, D.; Beechem, J.M.; Balko, J.M. Abstract 4978: Digital spatial profiling of molecular responses to nanoparticle STING agonists identify S100A9 and B7-H3 as possible escape mechanisms. Am. Assoc. Cancer Res. 2019, 79, 4978.

123. Konno, H.; Yamauchi, S.; Berglund, A.; Putney, R.M.; Mulé, J.J.; Barber, G.N. Suppression of STING signaling through epigenetic silencing and missense mutation impedes DNA damage mediated cytokine production. Oncogene 2018. [CrossRef] [PubMed] 